\title{
DETERMINANTS OF PRIVATE INVESTMENT IN ETHIOPIA A Time Series Study
}

\author{
Ambachew Mekonnen Sisay ${ }^{1}$
}

\begin{abstract}
In the growth literature, investment has been regarded as one of the primary engines of growth. Growth theories emphasise the importance of investment in determining the level of income (neoclassical) and the pace of economic growth (endogenous growth model). However, the Ethiopian private investment performance has been weak for long time. It had been stagnantly low until the end of the socialist regime. In spite of little improvement in the post-socialist era, the share of private investment in GDP has never been above 6 percent even until 2003. Yet, the reasons behind the weak performance have not been well studied. Hence, investigating the performance trend and maim constraints of private investment in Ethiopia becomes the core theme of this study. Targeting at addressing a question of what measures should be taken to promote investment in the country, the research proceeds to test empirically whether demand augmenting and trade liberalization policies, improved infrastructural facilities, macroeconomic and political stabilities improve the private investment performance of Ethiopia. Motivated by the modified version of the Flexible Accelerator Model of investment behaviour, the empirical investigation employs a multivariate single equation ECM estimation methodology on integrated of order one, 1(1), variables using annual time-series data sets for 1950-2003 and two sub-periods. According to the estimation results, private investment in Ethiopia is influenced positively by domestic market, return to capital, trade openness and liberalization measures, infrastructural facilities and FDI; but, negatively by government activities, macroeconomic uncertainty and political instability. Hence, enhancing demand augmenting and trade liberalization policies, improving infrastructural facilities and maintaining macroeconomic and political stabilities should be among the main ingredients of a policy package designed to promote private investment in Ethiopia. Furthermore, the operations of the public sector and other institutions will need new thinking.
\end{abstract}

Keywords: Investment, Determinants, Time-Series, ECM, Ethiopia

JEL Classification: E22, O16.

\footnotetext{
${ }^{1}$ School of Economics, University of Kent at Canterbury Address for correspondence: Ambachew Mekonnen Sisay, Office B1.07, School of Economics, University of Kent, Canterbury, Kent, CT2 7NP, UK. E-mail: am497@kent.ac.uk, or ambachewmekonnen@yahoo.com, Mobile: +44(0)7601068626.
} 


\section{Introduction}

Investment is an act of current spending for expected future return. It expands the productive capacity of a nation and plays a crucial role in the economic growth and development process. Investment has been regarded as one of the primary engines of growth (Wade, 1989, P. 71, UNCTAD, 2001, P. 1) and the proposed solutions to SSA economic and geographic disadvantages (Sachs, 2005, P. 273). It seems why almost all nations try to motivate the internal and attract foreign investment. However, investment performance varies across borders and over time. Hence, what determine investment spatially and temporally remains a vital question.

Based on the general emphasis of growth theories on the importance of investment in the process of economic growth, and the evidence from our recent studies where investment is found to be a positive determinant of economic growth and trade performances of SSA economies (see Mekonnen, 2011a \& 2011b, forthcoming), this paper extends the search for the main determinants of investment, with a case study of one SSA country, Ethiopia. As one of the least developed countries, Ethiopia has been backward in socio-economic development. Agriculture has been the main source of income and stay of the population while the industrial sector lingers thin, yet. The Ethiopian economy has been deteriorated by prolonged internal and external wars, wrong policies and recurrent drought coupled with ever-rising population resulting into economic stagnation, image deterioration and unattractiveness to investment expansion in spite of the recent revival. Understanding the Ethiopian investment process is important as its economy still remains agrarian. But, to the best of my knowledge, the Ethiopian investment and its constraints have not been well researched. Therefore, this study attempts to contribute to the investigation of the trends and main determinants of investment in Ethiopia, and tries to address the question of what measures should be taken to promote investment in Ethiopia? Therefore, as its objectives, the study focuses on assessing the trend, identifying the main determinants of private investment, and suggesting policy directions that could favour investment in the country.

The rest of this paper is organized as follows. The next section reviews related literature; section three describes the investment performance of the country; 
section four presents the theoretical frameworks and discusses estimation results while section five concludes the study.

\section{Literature Review}

\subsection{Investment and Its Growth Implications}

Investment has been regarded as crucial for growth since the formal onset of economics by the optimistic classical economist Adam Smith (1776). The belief of economists including the views of classical optimists and pessimists, Thomas Malthus (1798), David Ricardo (1817), and Karl Marx (1847)), Keynesian, neoclassical and endogenous growth theorists has been consistently the same in that the level of income and living standard of nations is a function of investment and capital accumulation. With the exception of neoclassical view, all the above blocks of thinking agree that economic growth depend on the rates of saving, investment and capital accumulation.

Thirlwall (2003) explains the main essence of Smith's models as "The growth of output and living standards depends first and foremost on investment and capital accumulation. Investment in turn depends on savings..." (P. 127). Despite its prediction on the independence of steady state growth on the rates of saving and investment, neoclassical model also emphasises the importance of saving and investment in determining the level of per capita income and living standards in the long run (Jones, 2002, P. 32, Thirlwall, 2003, P. 143, Sorensen and Whitta-Jacobsen, 2005, P. 77, Romer, 2006, P. 18-19). Sorensen and Whitta-Jacobsen (2005) assert "According to the Solow model, policies to make a nation richer should mainly be policies that can increase the investment share of GDP and bring population growth under control, or policies to improve technology" (P. 87). The new growth theory, on the other hand, adheres that in the long run savings and investment ratios influence growth, positively. The general set of implications of endogenous growth theory is societies that save and invest more will grow faster in the long run (Barro, 1991, P. 429, Plosser, 1992, P. 67).

In general, all growth models extending from the classical to the contemporaneous neoclassical and endogenous growth thoughts have given crucial roles to saving and investment in determining, at least, the level of per capita income and standard of 
living (neoclassical), or the rate of growth of output and living standards albeit in varying approaches and degrees of emphasis. Policy makers and practitioners also underscore the requisite of investment to growth and development. In emphasizing the importance of investment in the process of growth, Bellemore (1964), for instance, explains the role of investment as a vital one. According to him, the greater the production and employment of capital goods, the greater the capacity to produce goods and services. The economic essence of investment is attached to capital formation. The process of capital formation is self-generating. A larger stock of capital goods will allow greater production; greater production will produce a potentially larger surplus to be saved in capital goods; and so on. This is the manner in which the productivity of workers and the level of living could be improved (P. 1). Furthermore, in their applied research paper on the Namibian economy, Shiimi and Kadhikwa (1999) say the effects of investment on economic growth are two-fold. Firstly, it generates part of aggregate demand in the economy stimulating production of investment goods which in turn leads to high economic growth and development. Secondly, capital formation improves productive capacity; investment in new plant and machinery raises productivity growth by introducing new technology which could also lead to faster economic growth (P. 4).

After recognizing the strategic significance of investment in the process of improving human life, the immediate question that comes into mind is how it could be financed? In addressing it, economists stress the importance of domestic saving. After his extensive analysis, Arthur Lewis (1965) says "...investment is necessary for economic growth. From this it follows, in a passive sense, that saving is necessary to growth, because investment has to be matched by saving." (P. 213-214). However, part of Lewis' emphasis and Bellemore's (1964) idea on national saving as the only source of domestic investment seem obsolete. In today's integrated world, domestic saving is not the only source of investment. International capital mobility has been increasing dramatically in that a country may finance part of its domestic investment via capital imports or it may invest part of its savings abroad by capital exports.

Nonetheless, domestic saving remains the main source of investment financing of countries. The cumulative circular causation of saving-investment-growth, thus, could be explained as a continuous self-generating and self-reinforcing process in that one perpetuates the other resulting in a virtuous (vicious) circle of growth 
(poverty) if the process is positive(negative). Hence, promoting investment by raising the propensity to save, particularly for developing countries, is regarded as a panacea for many economic problems.

\subsection{Survey of Empirical Studies on the Determinants of Investment}

A number of studies have been conducted on the rise and fall of domestic investment and the flow of FDI in different countries. Many are devoted at drawing the trend and identifying the main determinants of both domestic investment and FDI. Despite variations and differences in relative influences, factors appearing in many of the studies are more or less similar. In their studies on the main determinants and the linkage between domestic investment and FDI, Shiimi and Kadhikwa (1999, P. 9-13, on Namibia), Astatike and Assefa (2005, P. 3-8, on FDI in Ethiopia), and, Ndikumana \& Verick (2008, P. 4, on Sub-Saharan Africa) have come out with much similar lists of factors affecting both domestic and foreign direct investment including natural resources, initial level of PCGDP, GDP growth, GDP per capita, economic structure (industrialization), surrounding market, expected return, human capital, domestic saving, labour inputs, access to credit and foreign exchange. Trade-related factors (openness, trade connection, export orientation, trade liberalization, degree of competition), macroeconomic stability (inflation, exchange rate volatility and BOP deficit), infrastructure, investment climate, corruption and red tape, efficient institutions, legal system, and lag effects of private investment, public investment and FDI are also in the list of the identified determinants.

There are also some surveys of studies highlighting the main determinants of investment. From the survey as well as their own empirical analysis, Nonnemberg and Mendonca (2004) found that the size of the market, the rate of GNP growth, economic stability, the degree of openness of an economy, human capital, administrative bottlenecks as well as several other institutional variables as the main determinants (P. 5-8). Similarly, Lee (2003) has surveyed about 15 empirical works and shown that most of the results of the studies have come out with contradictions. In most of the studies, GDP and GDP growth measuring size of domestic market and openness are found less controversial in influencing the flow of FDI positively while labour costs, trade barriers, exchange rate and trade balance 
variables have exhibited fragile properties in different studies. In justifying the contradictory findings of different studies, Lee has also mentioned problems of endogeneity and omitted variable bias as plausible reasons (P. 3-9). However, correcting for such econometric problems by including some other potential variables and using new measures of government barriers and policy indices, using panel data from 127 developing countries over the period 1995-2000, Lee (2003) has reached at the same conclusion in that a country's market size, openness to trade and government policy liberalization are crucial factors of FDI (P. 18).

According to the studies reviewed, the main determinants of investment are found to include market size, resource availability, degree of openness and liberalization, human capital, macroeconomic stability, political stability, policy variables, investment climate, lag effects, incentive packages, risks involved, infrastructural and institutional facilities, among others. In any attempt to investigate problems in the investment performances and come out with remedial suggestions, one can investigate subsets of the above to identify the main ones within a certain spatial and temporal horizons. Thus, the next sections explore the long-term private investment performance of Ethiopia targeting at identifying the main determinants and quantifying their respective weights of influences.

\section{Performance Trend of Investment in Ethiopia}

Investment is regarded as one of the engines of growth and prosperity of nations. Since it mobilizes idle resources, be it material or human, investment has special importance for developing countries. Ethiopia, as a developing country, needs a huge surge of investment from both domestic and external sources. More or less, various investment policies have been designed and implemented since long time ago. However, the private investment performance trend of Ethiopia has been very low for a long time since 1950. Figure 1 indicates the long-term performance of private investment in Ethiopia. In per capita terms, private investment has never been above 35 US\$ until 2003. It also shows that its performance has been below the full trend for 30 continuous years (1964-93). Below trend performances are mostly associated with either political chaos or natural disasters. 


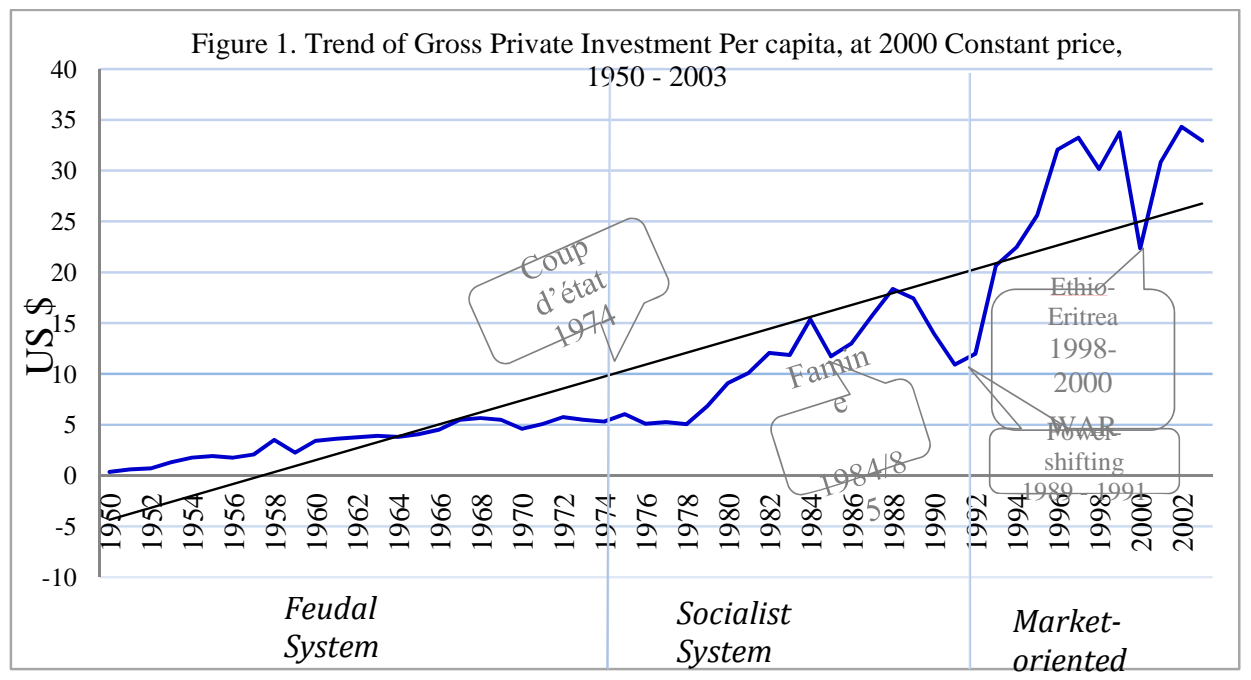

Source: PWT Version 6.2, 2006 (RGDPPC \& Share of GINV in RGDPPC)

The share of private investment in GDP and its contribution to the development process of the country have been at their extreme low levels. Its contribution to GDP has never been above 6 percent. In the period considered, its highest contribution to GDP was recorded to be $5.75 \%$ in 1996 while its lowest was 2.82\% (1991). Figure 2 displays the fluctuation of the percentage share of investment in GDP around its flat time-trend with a slight rise in its contribution since 1993.

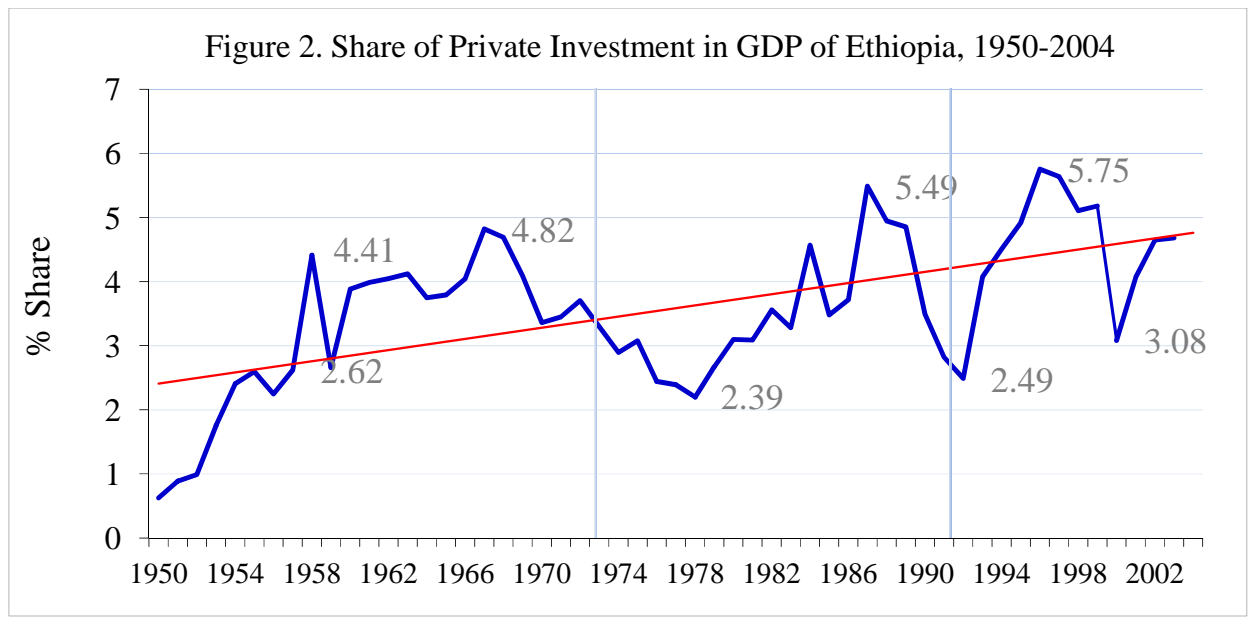

Source: PWT Version 6.2, 2006. 
According to Figure 2, the share of gross investment to GDP was below its trend in the pre-1984, 1985-1987, 1990-1994 and 2000-2001 periods. In fact, the investment share of GDP could fall because of either the deterioration of investment performance (numerator) or the improvement of the whole economy (denominator). However, the above periods of below-trend performances coincide with the chaotic situations of the country either because of policy measures such as nationalization or outbreak of extensive war or severe drought. The pre-1984 period is known for its vindictive nationalization \& expropriation of privately owned enterprises, houses and other properties. As of 1983, the number of nationalized enterprises was 159 (Selvam, 2007, P. 67). Years 1985-1987 represent the period following the 1984/85 Ethiopian famine where as the period 1990-1994 and 20002001 are periods comprising years of extensive wars that overturned the socialistic regime and the Ethio-Eritrean border wars, respectively. Hence, it could be reasonable to mention, the devastating famine of $1984 / 85$, the nationalization and repressive policy measures of the pre-1991, the power-shifting extensive/intensive civil war and its hangover after 1991/92 and the 1998-2000 Ethio-Eritrean border war as some of the major causes for the deteriorated investment performance of the country, below-trend and below its international comparators for most of the period since 1950.

Compared with three SSA countries, i.e., Kenya, Nigeria and South Africa, the Ethiopian private investment share of GDP has been found to be the least of all for the whole period considered with a special evidence of equivalence to that of Nigeria in the pre-1971 and the post-1985. However, the equivalence is due to the declining share of investment in GDP of Nigeria; not because of improvements in Ethiopia. Perhaps reflecting the de-industrialization process that hit the region, decapitalization is the general trend in all comparators since 1981 (see Figure 3). 


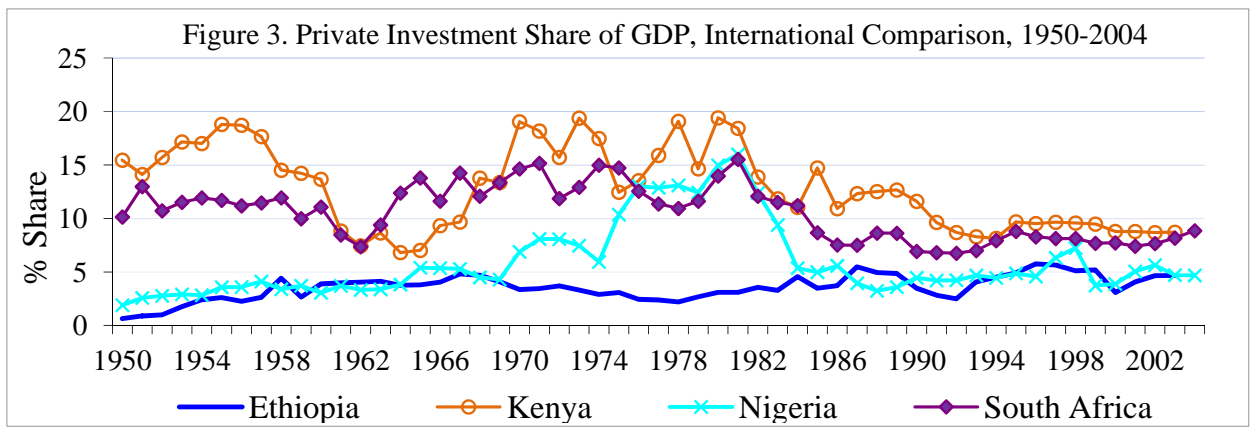

Source: PWT Version 6.2, 2006

The pre-1996 low investment performance pattern is also reflected by the overtime trend and fluctuations of the percentage share of the stock of FDI to GDP (Figure 4). The figure shows the low percentage share of the stock of FDI to GDP of Ethiopia which had been below average of the world, developing, African and East African countries and that of Kenya almost up to 1996 and its sharp rise during the post1996 period, surpassing all in the 2003-2004 period. It seems due to this fact that UNCTAD (2002) has classified Ethiopia in a group of countries with "low potential but high performance to FDI'.

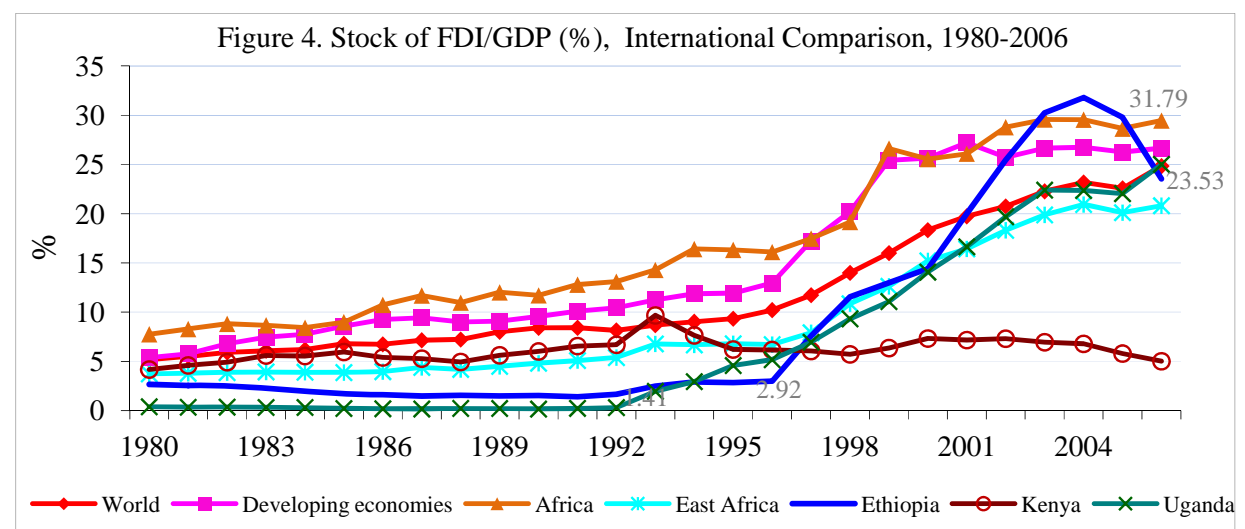

Source: UNCTAD, FDI on-line database, 2007

The rise of the share of the stock of FDI in GDP had slowed down in the period 19982000 followed by its revival reaching a peak in 2004 until it sharply contracted in the years since 2005. The unique event in 2005 was the national election held on 15 May, 2005 resulting in an unprecedented "vote-claiming" political turbulence that 
lingered for the subsequent few years since the overturn of the socialist regime. The decline in the share of the stock of FDI in GDP is attributed to the aftermath of the political unrest triggered by the result of the 2005 election.

Nonetheless, the dominant form of investment in the country is domestic investment. Figure 5 illustrates the overtime value-trends of domestic investment and FDI. Until 1994, even for the subsequent two years, the role of FDI relative to the total investment, measured with national currency, Birr, had been negligible. Its role, with little improvement since 1994, has exhibited significant swing since 1996. Marked as a point of inflection, 1991 is assumed as a year of reference for the policy shift from the pre-1991, inclusive, to the post-1991. Domestic investment has tended to rise since 1992 while FDI did since 1996 despite the 1998-2000 war had caused it to slump again (see Figure 5).

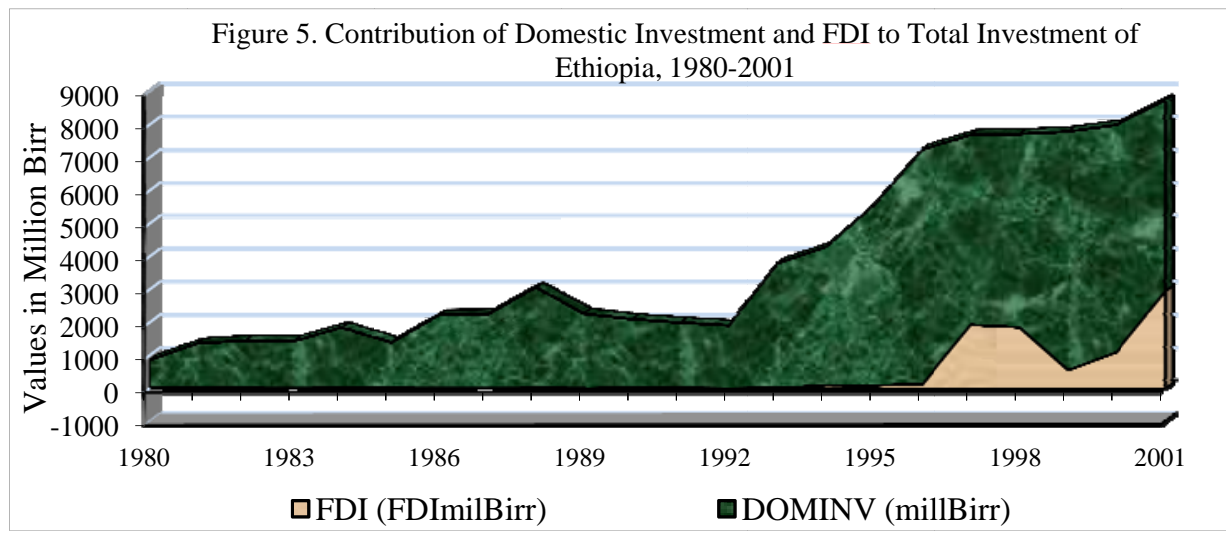

Source: IMF, IFS database, 2005 (DOMINV \& Ex/Rate), UNCTAD, FDI on-line database, 2007 (FDI in \$) and Own Computation (FDI in Birr)

The above facts and figures enable us to deduce that the dominant feature of Ethiopian investment is the domestic one with the rising role of FDI since 1996. However, during and after the Ethio-Eritrea border war, FDI had also fallen to its trough in 1999 followed by its revival after 2000 until it sharply contracted following the 2005 election. The overtime investment performance trend can be segmented into three distinct patterns; i.e., annual gross private investment, in per capita terms, amounting below 10 US\$ (1950-1981), between 10 to 20 US\$ (1982-1993) and above 20 US\$ (post-1993). Year 1991, marked the end of the socialist era and 
the beginning of the transition towards the liberal/market oriented system, is clearly identified as the starting point in time for the revival of private investment in Ethiopia. The relatively better investment performances of the post-1992 period, noting the severe declines in 1998-2000 and the post-2005 few years, might have some sensible reasons linked with the policy stances of the respective regimes, stability, increased openness/liberalization moves, improved investment climate and other macroeconomic and institutional factors. Nonetheless, the identification of the main determinants needs a quantitative investigation; which has been dealt in the subsequent econometric sections.

From the descriptive analyses, we have observed that Ethiopian investment has been extremely weak as signified by its low values and share of investment to GDP. Gross private investment has been sluggish in the period 1950-1992 while it was reviving since 1993. Domestic investment is found to be the main facet of total investment, while FDI had been negligibly low until its slight resurgence in 19941995 and considerable swing since 1996.

We perceive also that the $1975-90$ and $1998-2000$ intense wars, the pre-1984 nationalization, \& the socialist orientation of the whole 1974-1991 have with no doubt devastated the seeds of investment in the country. The evil consequences of the 2005 national election have caused the stock of FDI to fall sharply for the subsequent few years. Hence, 1991 has been characterized as a year of reference for the induced policy shift. Based on his extensive descriptive analysis, Mekonnen (2008) has reported the observed co-movements of both domestic investment and FDI to some representative variables of political instability, macroeconomic instability, market size, infrastructural facilities and trade liberalization measures. In addition, he has also noted that foreign reserve, exchange rate, domestic credit, inflation, real GDP and number of telephone subscribers (so lately) have shown relatively faster rises since 1992 (P. 52-53).

Thus, it is presumed that political and macroeconomic instabilities might have affected the growth of domestic private investment as well as FDI adversely while openness and liberalization, growing income and infrastructural facilities seem influenced them positively. 


\section{Empirical Analyses on the Main Determinants of Investment in Ethiopia}

\subsection{Theoretical Background of Investment Behavior}

In explaining investment behavior, a few theoretical models are at work in different literatures underpinning studies on investment decisions and serving as departures for their variants and extensions. Among those, the Accelerator, the Liquidity, the Expected Profits also known as the Cash Flow or Tobin's $q$ and the Neoclassical models of investment behavior have wider coverage in investment literatures.

The Accelerator theory of investment, as proposed by Carver (1903), Aftalion (1909), Bickerdick (1914) and Clark (1917) in its rigid version, and subsequently developed by Chenery (1952), Koyck (1954), Leeuw (1962) and Evans (1967) into its flexible version, explains that investment decision of a firm is determined by changes in demand for its produces (Song et al, 2001, P. 229). In accelerator theory of investment behavior, desired capital $\left(\mathrm{K}_{\mathrm{t}}{ }^{*}\right)$ is proportional to output $\left(\mathrm{Y}_{\mathrm{t}}\right)$ expressed as $\mathrm{K}_{\mathrm{t}}{ }^{*}=\alpha \mathrm{Y}_{\mathrm{t}}$ (as in the Aftalion-Clark simple or rigid version); and, actual capital, $\mathrm{K}_{\mathrm{t}}=$ $\mu \alpha Y_{t}$ (as in Chenery and Koyck flexible version), where $\alpha$ is the desired capital-output ratio and $\mu$ is a constant parameter of adjustment (Jorgensen and Siebert, 1968, P. 694). The main implication of the model is that the investment expenditure of an investing firm is proportional to its output while its output is a function of demand.

The Liquidity theory of investment behavior developed by Meyer and Kuh (1957) and Duesenberry (1958) proposes desired capital to be proportional to the internal fund (liquidity, $L_{t}$ ) available for investment, i.e., $K_{t}{ }^{*}=\alpha L_{t}$, where $L_{t}$ is profits after taxes plus depreciation minus dividend paid, and $\alpha$ is the desired ratio of capital to the available internal fund (Ibid, P. 694).

The Expected Profits (Cash Flow) theory of investment formalized by Grunfeld (1960) explains desired capital as a proportion of the market value $\left(V_{t}\right)$ of a firm, $K_{t}{ }^{*}=\alpha V_{t}$, where $\alpha$ is the desired ratio of capital to market value of a firm. Tobin (1969) has also proposed a model regarded as a generalization of the Expected Profits model in which investment expenditure is related to the ratio of the market value of business capital assets $\left(V_{t}\right)$ to the replacement value $\left(\delta_{t}\right)$ of those assets. This ratio is known 
as Tobin's q, where $q_{t}=\left(\frac{V_{t}}{\delta_{t}}\right)$. According to the model, a value of q closer to 1 or greater encourages investment while a lower value of q discourages it.

The Neoclassical theory of investment behavior developed by Jorgensen (1963) as advanced by Hall and Jorgensen (1967) equates desired capita stock to the value of output deflated by the price of capital services $\left(c_{t}\right)$ including or excluding capital gains, $\left(\frac{q_{t}-q_{t-1}}{q_{t}}\right): \mathrm{K}_{\mathrm{t}}{ }^{*}=\alpha \frac{P_{t} Y_{t}}{c_{t}}$; where $\mathrm{P}_{\mathrm{t}}$ is a constant wholesale output price index, $c_{t}=\left(\frac{q_{t}}{1-u_{t}}\right)\left[\left(1-u_{t} w_{t}\right) \delta+r_{t}-\frac{q_{t}-q_{t-1}}{q_{t}}\right], \mathrm{q}_{\mathrm{t}}$ is the investment goods price index, $\delta$ is the rate of capital replacement, $r_{t}$ is the cost of capital, $u_{t}$ is the rate of taxation of corporate income, $w_{t}$ is the proportion of depreciation at replacement cost deductible from income for tax purposes (Jorgensen and Siebert, 1968, P. 695 - 697, Song et al, 2001, P. 230). At the core of this model is the importance of the value of output in influencing investment decisions; thus, it is regarded as a version of the flexible accelerator model (Salahuddin and Rabiun, 2008, P. 21-22).

Thus, attracted by its generalization and its proposition on the proportional relation of investment expenditure with demand for products, a modified version of the flexible accelerator theory of investment behaviour is dominantly at work in studies designed to identify the determinants of investment in the developing world. For instance, Wai and Wong (1982), Blejer and Khan (1984) on the determinants of private investment in developing countries, Ramirez (1994) on public and private investment in Mexico and others have employed the modified version of the flexible accelerator investment model with the incorporation of different macro characteristics of developing countries, in both time series and panel data analyses.

Hence, this study adopts the practice of employing the flexible accelerator model augmented with characteristics presumed to constrain the investment performances of SSA as a theoretical foundation of our attempt to identify the main determinants of investment with a case study on Ethiopia. Consequently, the derivation and the main implications of the flexible accelerator model have been highlighted as follows, underlying the specification of the empirical model. 


\subsection{The Model of Flexible Accelerator Investment Behavior}

The simple accelerator investment theory proposes the idea that investment responds immediately and entirely to changes in demand conditions to close the gap between the desired stock of capita $\left(\mathrm{K}_{\mathrm{t}}{ }^{*}\right)$ and the existing stock of capital goods left from the previous period $\left(\mathrm{K}_{\mathrm{t}-1}\right)$.

$$
I_{t}^{*}=K_{t}^{*}-K_{t-1}
$$

However, demand shocks may not be permanent; instead of responding to the demand shocks instantaneously and entirely, a firm, adaptively, may adjust its capacity gradually. Thus, desired investment $\left(\mathrm{I}_{\mathrm{t}}^{*}\right)$ would be only a fraction $(\alpha)$ of the size of the change in demand $\left(Y_{t}-Y_{t-1}\right)$.

$$
I_{t}^{*}=\alpha\left(Y_{t}-Y_{t-1}\right)
$$

Where $\alpha$ is a constant desired capital-output ratio $\left(\alpha \frac{K_{t}}{Y_{t}}=\frac{K_{t-1}}{Y_{t-1}}=\ldots . \frac{K_{t-n}}{Y_{t-n}}\right)$

Moreover, actual investment $\left(\mathrm{I}_{\mathrm{t}}\right)$ of a firm may not fully cover the desired level of investment $\left(\mathrm{I}_{\mathrm{t}}^{*}\right)$ instantaneously due to reasons like the supply constraint of the capital goods industries, delivery/installation lags, etc. Hence, actual investment $\left(\mathrm{I}_{\mathrm{t}}\right)$ which amounts the size of a change in capital stock $\left(\mathrm{K}_{\mathrm{t}}-\mathrm{K}_{\mathrm{t}-1}\right)$ is a certain fraction $(0<$ $\mu<1$ ) of desired investment,

$$
I_{t}=K_{t}-K_{t-1}=\mu l_{t}^{*}
$$

Where $\mu$ is a constant parameter of adjustment calculated as a ratio of actual investment to desired investment $\left(\mu=\frac{I_{t}}{I_{t}^{*}}=\frac{I_{t-1}}{I_{t-1}^{*}}=\ldots \frac{I_{t-n}}{I_{t-n}^{*}}\right)$ and $n$ is the number of lags.

With repeated substitution and iteration, capital stock at period $t$ can be retrieved as a certain fraction $(\mu \alpha)$ of the accumulation of declining fractions of output of the past $n$ lag periods, where $n=0,1,2, \ldots ., \infty$. 


$$
K_{t}=\mu \alpha \sum_{n=0}^{\infty}(1-\mu)^{n} Y_{t-n}
$$

Analogously, capital stock at time $\mathrm{t}-1$ can be derived as

$$
K_{t-1}=\mu \alpha \sum_{n=0}^{\infty}(1-\mu)^{n} Y_{t-n-1}
$$

Recalling equation (2), actual investment at period $t$ is given by $\mathrm{I}_{\mathrm{t}}=\mathrm{K}_{\mathrm{t}}-\mathrm{K}_{\mathrm{t}-1}$. By replacing eq (4) in place of $K_{t}$ and eq (5) in place of $K_{t-1}$, the actual investment function can be derived as:

$$
I_{t}=\mu \alpha \sum_{n=0}^{\infty}(1-\mu)^{n}\left(Y_{t-n}-Y_{t-n-1}\right)
$$

Thus, equation (6) is the general representation of the flexible accelerator model of investment. According to the model, (i) actual investment at time $t\left(I_{t}\right)$ is a constant fraction $(\mu)$ of the desired investment which, in turn, is a fraction $(\alpha)$ of past changes in output or aggregate demand; (ii) desired investment is not determined solely by the current change in output but also by earlier changes in output; (iii) the constant ratio of actual to desired investment, a number between 0 and $1,(0<\mu<1)$, implies that when the exponent $n \rightarrow \infty,(1-\mu)^{n} \rightarrow 0$, i.e., geometrically-decaying distributed lag effects. This in turn entails the earlier the output change, the less is its effect on the current desired investment justifying the consideration of the recent.

However, the unrestricted lag structure of the flexible accelerator model tends to cause multi-collinearity problem in estimations, generates misleading results and makes empirical characterization of the time structure of investment implausible (Jorgensen and Siebert, 1968, P. 687, Song et al, 2001, P. 229). In addition, many potential determinants such as wage rates, interest rates, taxes, and other macroeconomic and investment climate indicators are not included in the determination of investment, which is difficult to justify on both theoretical and practical grounds (Song et al, 2001, P. 229). Because of such intrinsic shortcomings, the model is applied with modifications and inclusion of different sets of variables in 
various studies. As part of our modification, if we disregard all the lags $(n=0)$, the model would be simplified into:

$$
I_{t}=\mu \alpha\left(Y_{t}-Y_{t-1}\right)
$$

\subsection{Single Equation Specification on the Determinants of Investment}

According to the flexible accelerator theory of investment behaviour, actual investment is a function of changes in demand or output.

$$
I N V=f(G D P)
$$

However, the model is usually employed with modifications; i.e., simplifying the lag structure and inclusion of other characteristics to which researchers are interested in explaining investment. Following this practice, we have also considered other variables in addition to demand; i.e., trade, return to capital, infrastructure, macroeconomic instability/uncertainty, political instability and FDI. This modification renders us to expand the functional form as:

$$
I N V=f(G D P, \text { return, trade, inflation, infrastructure, }, \ldots . . D w)
$$

However, there are a few difficulties and further interests that would not be handled by a straightforward estimation of the above functional representation of investment behaviour in the case country; i.e., separating the effects of return to $K$, effective demand and government activities. The details of the difficulties and the approaches followed to tackle them are discussed as follows.

Under perfect capital market assumption, the rate of return to capital is captured by real interest rate in line with Keynesian Marginal Efficiency of Investment (MEI) theory. However, this and other assumptions underlying the standard model, typically, are unlikely to hold in developing countries where the financial sector is repressed/controlled (Oshikoya, 1994, P. 583, Asiedu, 2002, P. 110). According to Blejer and Khan (1984), while the rates of return on investment in developing countries typically tend to be quite high, real interest rates on loans are kept low by governments for a variety of reasons. They say also "It is interesting to note that, in 
the currently popular models of financial development, an increase in interest rates, by increasing financial savings, raises rather than lowers private investment" (P. 386). Inclined to this idea, Sakr (1993) has found negative but insignificant estimate for real interest rate in determining private investment in Pakistan (IMF Working Paper, P. 10). Shortly stating, these arguments imply that real interest rate particularly in developing countries fails to account for the return to capital.

Asiedu (2002) has also annotated the difficulty of finding an appropriate measure of the return on investment in developing countries and tried to mitigate it by assuming that the marginal product of capital is equal to the return on capital. According to her, this implies that investment in capital-scarce (poor) countries yields a higher return and proposes the use of the inverse of real per capita GDP to proxy return on capital, expecting inverse relationship between real GDP per capita and investment (P. 110 -111). Following these theoretical and practical arguments, the use of the inverse of per capita GDP is the approach proposed as a roundabout to capture the return effect.

However, the use of the inverse of per capita GDP as a proxy for the return on capital in an empirical work that bases on the accelerator theory of investment where demand is mostly proxied by GDP could seem reasonably strange. Despite the emphasis of the accelerator theory on demand for products, there are also other problems intrinsic to the use of GDP, identified from both theoretical and empirical sides of the argument.

From the theory side, the inseparability problem of the marginal efficiency of investment (MEI) and the accelerator theories of investment still remain a lacuna while employing GDP is the usual practice to represent demand. Vernor Smith (1961) explains that the micro-founded expression of investment demand as a function of the rate of interest, the rate of change of output and the level of output demonstrates the inseparability of "marginal efficiency" and "accelerator" theories of investment behaviour (P. 16). The approach followed by Asiedu to proxy the return to capital by the inverse of GDP per capita based on the Law of Diminishing Marginal Returns to Scale (LDMR) compounds the complication in using GDP as a measure of demand only. "The Law of diminishing return implies that the marginal 
product of capita is higher in the less productive (i.e. in the poorer) economy" (Lucas, 1990, P. 92).

According to MEl theory, investment demand and interest rate are inversely related. On the other hand, assuming other factors remaining constant, a change in income causes the demand for money and then interest rates to change in the same direction (Geithman, 1971, P. 115). Thus, increase in GDP could have an adverse pass-through effect on investment via increased interest rate as opposed to the accelerator principle. In addition, according to the LDMR, the richer is a country, the higher is the $\mathrm{K} / \mathrm{Y}$ ratio and the lower is the return to additional capital (investment). This is a second contradiction to the prediction of the accelerator theory of investment. Therefore taking the proposition of the three principles into account, one can expect that the net effect of GDP on investment to be positive (if the demand effect > the MEI + DMR effects) or negative (if the reverse happens) otherwise zero if the contradicting effects cancel-out one another.

Empirical works have also been reporting mixed evidences. As discussed above, one of the reasons for different empirical works that employed per capita GDP as a proxy for market to provide mixed results seems the inseparability problem of the MEI, return and accelerator effects. For instance, Lee (2003, P. 18), Nonnenberg \& Mendokca (2004, P. 5) have found a positive effect of per capita GDP or its growth; Edwards (1990), Jasperson, Aylward and Knox (2000) came out with significantly negative estimates while Loree and Guisinger (1995), Wei (2000), and Hausman \& Fernandez-Arias (2000) reported insignificant results (in Asiedu, 2002, P. 110). Kahai (2004, P. 48), Jenkins (2010, P. 53) and others have also reported insignificant results. In testing his postulate on the positive effect of the growth of GDP on private investment on 8 low and middle-income SSA countries, Oshikoya (1994) also has found mixed results; i.e., significantly positive (for the low-income group \& 4 countries), significantly negative (1 country) and insignificant (for the middle-income group) (P. 587).

According to the above arguments, estimating negative coefficients for GDP or per capita GDP does not mean that the demand effect is negative. It could rather be indicating the outweighing positive effect of the return to capital. But, this reality does not seem to be well checked and documented. Therefore, for reliable 
estimation, it is worthwhile to give attention to disentangle the two effects, i.e., the positive demand and the return effects, justifying our attempt of proxying the return to capital by the inverse of per capita GDP.

But, the aforementioned attempt could be fruitful if the impact of demand is effectively controlled. Motivated by our particular interest to investigate the effects of different components of demand (private consumption and government spending), in addition, we tried to bring demand into the regressions in disaggregate or components in separate, instead of aggregate demand. In doing so, due attention has been given to the independent influences of private consumption and government expenditures. This approach could also help us to remove the investment component from GDP and alleviate the danger of obtaining spurious results.

The use of private consumption to represent demand is consistent with the special emphasis of the acceleratory theory on consumer demand in determining private investment. In his basic text book, John Sloman (2003), for instance, explains the four main determinants of investment to include 'increased consumer demand, expectations, the cost and efficiency of capital equipment and the rate of interest'. According to him, investment is required to provide extra capacity which is only necessary if consumer demand increases; the bigger the increase in consumption demand, the more investment will be needed. Stressing the importance of consumer demand in explaining investment via accelerator principle, Sloman (2003) says "the relationship between investment and increased consumer demand is examined by the accelerator theory" (P. 474). He provides further explanation on the magnificent role of consumer demand in determining investment decisions (P. 484485). This emphasis is an extension of the theoretical articulation of Paul Samuelson (1939). According to Samuelson (1939), the introduction of the relation that assumed induced private investment to be proportional to the time increase of consumption accounts for the novelty of the conclusions reached in Professor Hansen's development of a new model sequence which combines the multiplier analysis with that of the acceleration principle or relation (P. 75). In revisiting Samuelson's multiplier-accelerator model that combined the Keynesian multiplier analysis with the principle of acceleration, Professor Westerhoff (2006) has also mentioned the emphasis of accelerator theory on consumption component of demand as follows: 
"The accelerator principle states that induced investment is driven by changes in consumption, respectively by changes in national income" (P. 89).

Therefore, the use of private consumption as a measure of demand, the inverse of per capita GDP as proxy for return on capital (K) and the separate treatment of government spending is advantageous to achieve our intention of disentangling the three different effects that would have not been done by using aggregate GDP as a measure of demand; i.e., to test our expectations on the positive demand effect, mainly captured by private consumption, the net crowding-out effect of government spending, and the positive effect of return on capital.

Therefore, learning from other works and based on the objective of the research, this study employs the simplified version of the flexible accelerator investment model augmented with the inclusion of variables that could reflect domestic market (private consumption, government expenditure and lagged investment and FDI performances), political stability (war dummy), macroeconomic stability (inflation or foreign reserve), and trade openness and liberalization measures (export plus import to GDP ratio or the real values of exports and imports separately or a dummy variable). Hence, the general functional form of the model is formulated as:

$$
I N V=f(C O N S, \text { GOVE, RETURN, OPEN, INF, TELE, ....., DW) }
$$

Where, CONS is private consumption, GOVE is Government Expenditure, RETURN is the return on capital (the inverse of per capita GDP), OPEN - the ratio of the volume of export and import to GDP (proxy measure of openness) or DLIB - Liberalization Dummy (0 for pre-1991 and 1 for post-1991), INF - inflation (proxy measure of macroeconomic instability-1), FXRES - foreign exchange reserve (proxy measure of macroeconomic instability-2), TELE - number of telephone lines and mobiles per 100 people (proxy measure of infrastructure), DW - Dummy for political instability (1 for politically turbulent and war years and 0 for relatively peaceful years) and other variables. 
Based on the above functional representation, a multivariate $\operatorname{ARDL}(p, q)$ model is proposed

$$
y_{t}=\mu+\sum_{j=1}^{p} \theta_{j} y_{t-j}+\sum_{i=1}^{k} \sum_{j=0}^{q} \beta_{i j} x_{i, t-j}+u_{t}
$$

$$
u_{t} \sim \operatorname{iid}\left(0, \sigma^{2}\right)
$$

Where, $y$ stands for investment, $\sum_{i=1}^{k} x_{i}$ is a vector of $k$ explanatory variables (determinants of investment), $i=1, \quad 2, \ldots, k$. $\boldsymbol{\mu}$ - a constant term, $\boldsymbol{\theta}$ and $\boldsymbol{B}$ - the coefficients to be estimated and $u$ - the random error term while $t$ is a time identifier.

With the help of the estimation of the above specification, we attempt to test the main hypotheses stated as whether demand augmenting and trade liberalization policies, improved infrastructural facilities, macroeconomic and political stabilities improve the private investment performance of Ethiopia.

\subsection{Variables and Data}

In identifying the main determinants of investment, this empirical analysis focuses on factors such as demand (consumption and government expenditures), return to capital (the inverse of real GDP per capita), trade policy (trade openness and liberalization), macroeconomic stability (inflation or foreign reserve), infrastructure (telephone density) and political instability (war dummy constructed based on the historical data obtained from Armed Conflict online database).

In the analysis, annual time series data sets covering the past five decades (19502003) with a total of 54 observations and two sub-periods, i.e., 1965-2003 \& 19702003 are used, complementarily. Except for the expenditure components of GDP, all the data series are given in ratio scale. The GDP data series is given in 2000 constant US dollar price, adjusted for Terms of Trade (TOT) changes while its components, i.e., consumption, government expenditure and investment, are given in percentage shares. Hence, multiplying the corresponding shares and GDP and then dividing by 
100 generates the annual real dollar value of the variables, adjusted for TOT that could be employed for the analysis (see Appendix Table 1 for further details).

\subsubsection{Data Characterization}

The underlying data collected/generated are all value data of gross private investment (INV), foreign direct investment (FDI), private consumption (CONS), government spending (GOVE), macroeconomic variables such as foreign reserve (FXRES) and inflation (INF), measure of openness (OPEN) and alternative measures of income like real per capita GDP (RGDPPC) and growth of per capita GDP (grgdppc). In addition, two dummy variables have been defined characterizing the period into war years of the 1962-1990, 1998-2000 and other politically turbulent years (values of 1) versus the relatively peaceful years of the 1950-1961 \& 1991-97 (DW) (values of 0); and liberalization move (DLIB) of the country in that DLIB is assigned to have 0 values for the pre-1991 inclusive and 1 for the post-1991 years. Except GDPPC growth and the dummies, all the data series have been transformed into log levels to dampen short-run fluctuations and skewed distributions in the realizations of the stochastic process.

As the variables defined above are typical time series, they may involve nonstationary or unit root process. Working with a non-stationary time series in that the mean, variance and covariance are not time-invariant leads a researcher to end-up with a spurious regression superficially looking good fit but seldom reflecting the true relationship between the variables of interest. Hence, to tackle such problems, stationarity tests have been undertaken prior to using the data to construct a model. This is done by the informal graphical diagnostic and the formal Unit Root tests of stationarity in that the Augmented Dickey Fuller (ADF) tests are used.

\section{(i) Graphical Examination of the Data}

As a first step, informal graphical diagnoses are visualized in the following figures plotting graphs, autocorrelation and partial autocorrelation correlograms of the log levels of each series and their first-difference counterparts for the series with full data availability for over the whole sample period. If a stochastic process is purely random, its value series is non-trending and its autocorrelation at any lag greater 
than zero is zero. However, according to Figure 6 , all the variable series are trending upward persistently with high fluctuation in the logarithmic value of foreign exchange reserve followed by real per capita GDP and trade openness variables. The corresponding ACF represented by the autocorrelation correlograms reveal the persistent correlation between successive lags of the log-levels series indicating the non-stationarity of the processes. Hence, all the variables seem to exhibit nonstationarity (unit root) problem. However, one common feature of the correlograms as displayed in the lower panel of Figure 6 is that they start at a very high value at the first lag and taper-off to the $6^{\text {th }}$ lag signifying the declining correlation as the time distance widens.

\section{Figure 6. Plots and Autocorrelation Functions (ACFs) of the Log-transformed data}
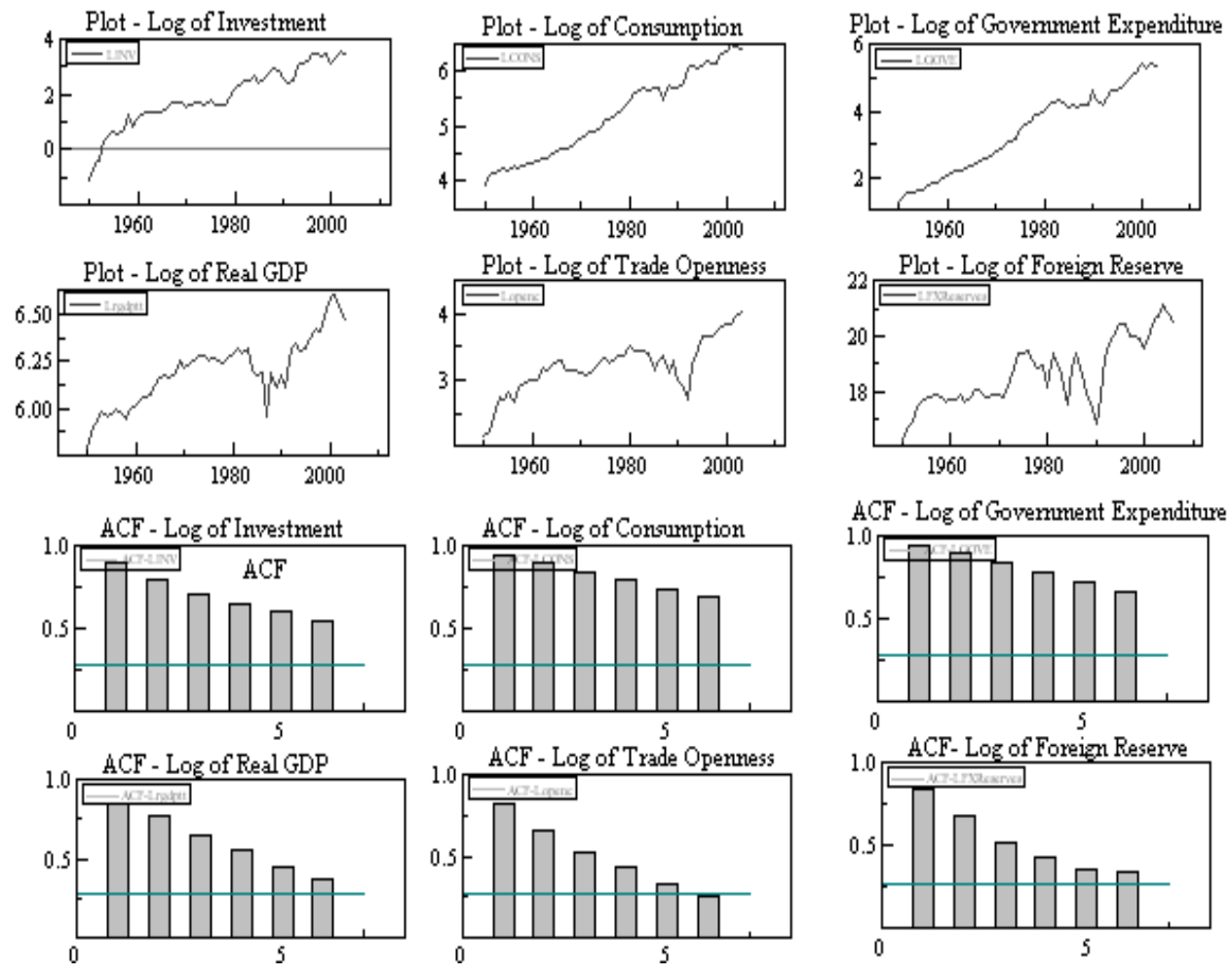

Furthermore, as indicate in Figure 7, the correlograms of the corresponding partial autocorrelation functions (PACF) reveal that only the autocorrelation of the first lag 
seems dominant and significant for all the variables that exhibit persistence. All the bars representing partial autocorrelation beyond the second lag, inclusive, are shown to remain within the $95 \%$ confidence interval or the error band of approximately $0 \pm 2 / \sqrt{T}$ where $T$ is time in years. This implies that, for the log-levels series, the persistence is strong and significant only for one period.

Figure 7: Partial Autocorrelation Functions (PACFs with $0 \pm 2 v T$ error bands)
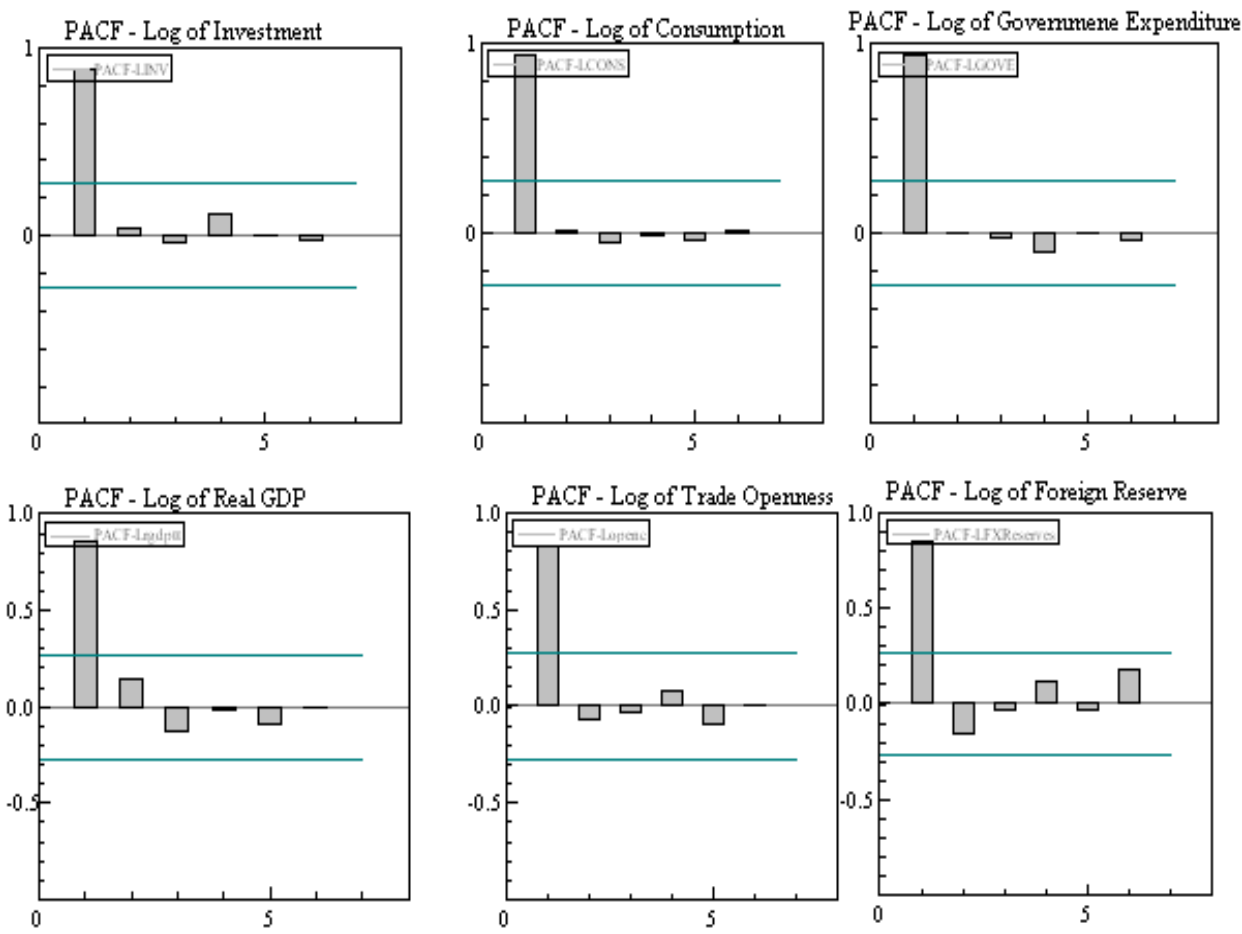

This idea is also backed by the non-trending plots of the first-differences of all the variables. However, we should note that the variation of the first-difference of the log of foreign exchange reserve seems time-variant which could have adverse implications on some of the required data proprieties, i.e., normality and constant variance. 
Figure 8: Plotting Plots of the First-Differences (Growth Rates) of the Data

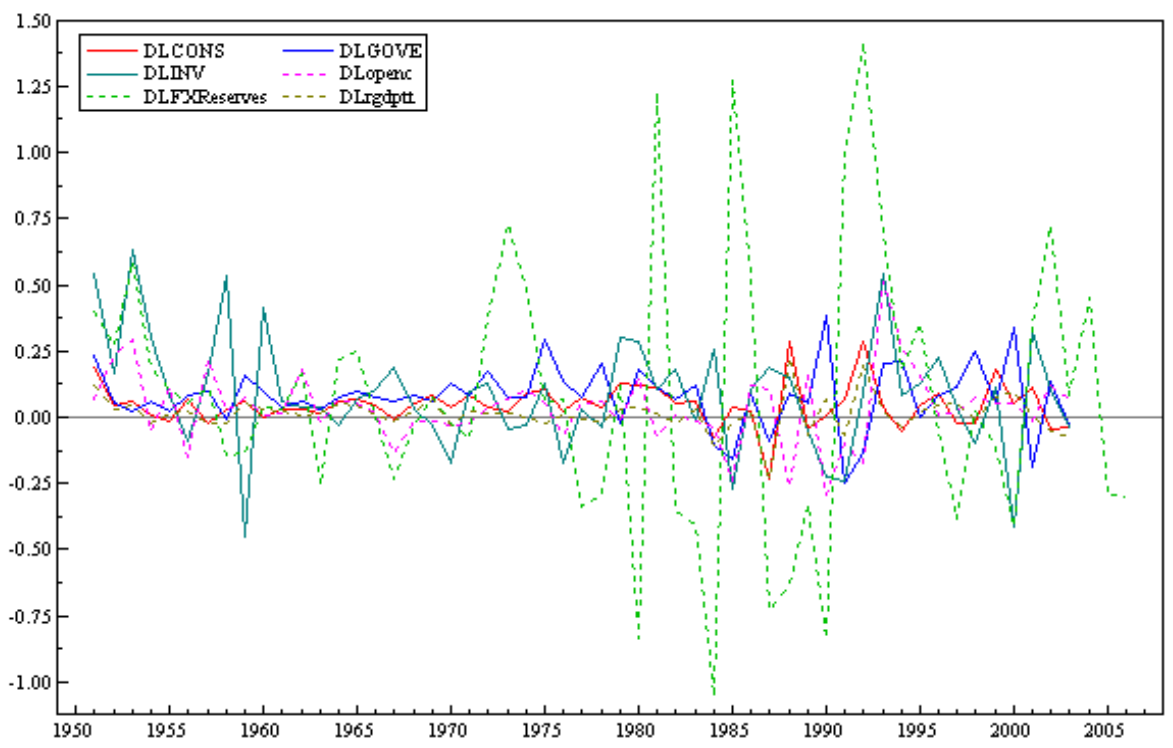

Thus, we can judge at a glance that the levels data from all these variables exhibit clear upward trend signifying persistence and non-stationarity while all their firstdifferences seem stationary. Nonetheless, it is insufficient to conclude on the stationarity of the series solely by looking at their plots. In addition, there are other variables that are not considered in the graphical diagnosis due to limited data availability. Thus, following the judgment based on the graphical diagnosis, a comprehensive and formal Unit Root test of stationarity has to be conducted.

(ii) Unit Root Test of Stationarity

The formal Unit Root test of stationarity has been conducted on the present and 4 lag values in that the ADF statistics are used at $5 \%$ and $1 \%$ significance levels as developed by Dickey and Fuller (1979) on the full range of the variables. For its advantage in accommodating higher order serial correlations over the DF and superior finite sample properties over the Phillips-Perron tests (Greene, 2003, P. 643-645), the ADF unit root test of stationarity has been employed based on the following autoregressive specification that contains lagged differences with the optional inclusion of a constant, or a constant \& trend: 
Ambachew Mekonnen: Determinants of private investment in Ethiopia:...

$$
\Delta y_{t}=\alpha+\mu t+(\beta-1) y_{t-1}+\sum_{i=1}^{p} \gamma_{i} \Delta y_{t-i}+\varepsilon_{t}
$$

In this test, the null hypothesis is that 'the underlying time series is non-stationary $(\beta-1=0$ implying a unit root)' against the alternative hypothesis of 'the time-series is stationary $(\beta-1<0)^{\prime}$. Hence, rejection of the null hypothesis implies stationarity of the series under consideration. As indicated in Table 1 , the ADF test on the levels data series does not reject the non-stationarity hypothesis at both $1 \%$ and $5 \%$ significance levels, except on log INV (inv) and log FDI (fdi) at 0-lag with constant \& trend while it does for the first-differences of all the variable series except tele/100 which only its second difference is stationary.

Table 1. Unit Root test Results with Constant, and Constant and Trend

Ho: Non-stationary

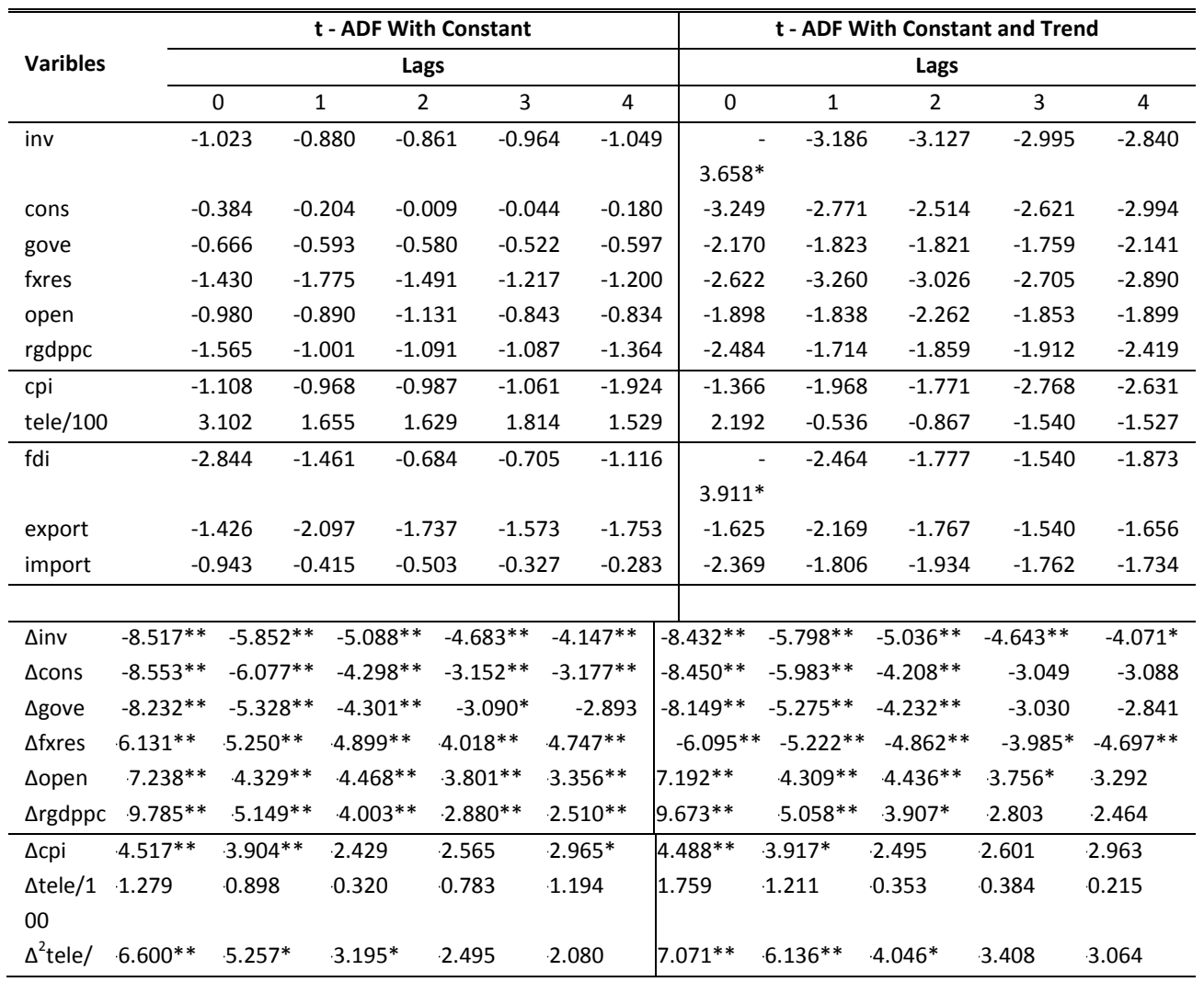


Ethiopian Journal of Economics, Volume XIX, No. 1, April 2010

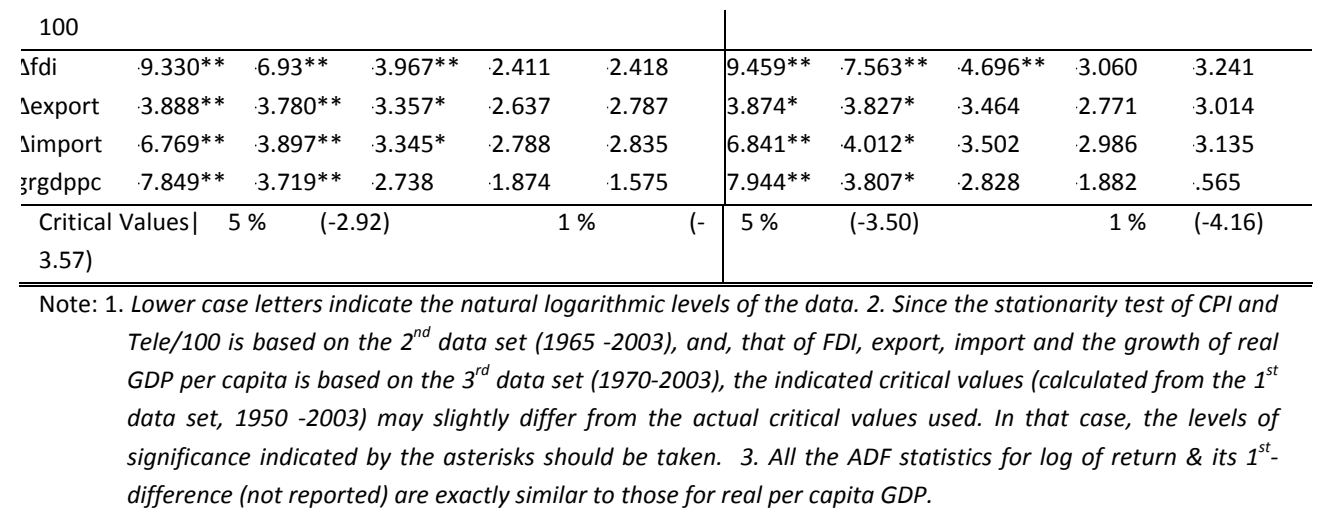

The Unit Root test of stationarity is not altered by the alternative inclusion of a constant or a constant $\&$ trend, for almost all the variables. Hence, we characterize the data series as all except tele/100 are integrated of order $1,1(1)$, while tele/100 is integrated of order $2,1(2)$.

\section{(iii) Cointegration Test}

Despite non-stationarity of the series, the linear combination of the variables could produce stationary process. If that is so, the variables are said to have cointegrating relationships. Therefore, it also needs a formal test of cointegration that could be conducted following either the Engle-Granger (1987) single equation residual-based or the Error Correction Mechanism (ECM) test in a single equation framework of Banerjee et al $(1986,1993)$ or Johansen's $(1988,1990,1995)$ VAR approach. However, the Engel-Granger (1987) test suffers from lack of power in finite samples while Johansen's VAR approach is data intensive placing limits on the number of variables and the lag length to be considered particularly in a short time-series data of this sort. Thus, our cointegration test employs the Johansen and the Banerjee et al approaches. But, due to the above reasons, in using the Johansen test, only the main five variables with the inclusion of up to three lags are considered. Johansen's Likelihood Ratio (Trace) test is a test of the rank of cointegration or the number of cointegrating vectors; i.e., null " $r \leq p$ " with the following steps:

$$
\operatorname{Trace} \text { Statistic }\left(\eta_{r}\right)=-T \sum_{i=r+1}^{M} \ln \left[1-\lambda_{i}\right]
$$


Where $r$ is the rank of cointegration;

$T$ is the number of usable observations;

$M$ is the number of endogenous variables; and

$\lambda_{i}$ is the next eigenvalue $\left(\lambda_{r+1}\right)$.

The trace test $\sim \chi 2(M-\lambda)$ with $M-\lambda$ degrees of freedom.

A Trace Statistic greater than the $\chi 2$ Critical Values leads into the rejection of the null " $r \leq p "$

The Johansen Trace test results are summarised in Table 2. The results suggest the existence of one cointegrating relationship between the variables when the dependent variable is considered while there is no cointegrating relationship amongst the regressors. The implication of the test results is the existence of shortrun and long-run relationships that could only be identified with the employment of Error Correction Model (ECM) as introduced by Phillips $(1954,1957)$, used by Sargan (1964), popularized by Hendry (1984) while Engle \& Granger (1987) linked it to the theory of cointegration (Hassler \& Wolters, 2006, P. 59; Banerjee et al, 1986, P. 265, 1998, P. 268).

\section{Table 2. Cointegration Test results}

HO: Co-integrating Rank, $r \leq p$, (where $p=0,1,2, \ldots . M-1)$

\begin{tabular}{c|l|l|l|l}
\hline \hline & \multicolumn{2}{|l|}{ With Investment and Regressors } & \multicolumn{2}{|c}{ Among Regressors only } \\
\hline $\begin{array}{c}\text { Null } \\
\text { Hypothesis }\end{array}$ & $\begin{array}{l}\text { Trace } \\
\text { Statistic [Prob] }\end{array}$ & Decision & $\begin{array}{l}\text { Trace } \\
\text { Statistic [Prob] }\end{array}$ & Decision \\
\hline$r=0$ & $76.575[0.012]$ & Reject HO: $r=$ & $42.695[0.140]$ & Do not reject \\
$r \leq 1$ & $* *$ & 0 & $18.889[0.512]$ & There is no \\
$r \leq 2$ & $40.363[0.212]$ & & $7.208[0.560]$ & cointegration \\
$r \leq 3$ & $18.430[0.545]$ & The number & $0.062[0.803]$ & among the \\
$r \leq 4$ & $6.878[0.598]$ & of & - & regressors. \\
& $2.436[0.119]$ & Cointegrating & & \\
& & vectors is 1. & & \\
\hline \hline
\end{tabular}

The number of lags used: 3 (Following Greene, 2003, P. 659)

Variables considered are Investment, Consumption, Government Expenditure,

Foreign reserve and Trade Openness (all in natural logs) using data for the full sample period.

Hence, based on the stationarity and cointegration test results, the model to be estimated is specified as a multivariate single equation ECM of the form 


$$
\begin{aligned}
& \Delta y_{t}=v+\lambda \widehat{\xi}_{t-1}+\sum_{j=1}^{p-1} \alpha_{j} \Delta y_{t-j}+\sum_{i=1}^{k} \sum_{j=0}^{q-1} \gamma_{i j} \Delta x_{i, t-j}+\varepsilon_{t} \\
& \varepsilon_{t} \sim \operatorname{iid}\left(0, \sigma^{2}\right) \\
& \hat{\xi}_{t}=\left(y_{t}-X 8\right) \\
& \hat{\xi}_{t-1} \text { is the error correction term (ECM) }
\end{aligned}
$$

For a dependent variable $y$ and a vector of $k$ explanatory variables, $X$, i.e.,

$$
\sum_{i=1}^{k} x_{i t}=X=\left(x_{1 t}, x_{2 t}, \ldots, x_{k t}\right)
$$

Following Pesaran and Shin (1999), various information criteria have been employed to determine the lag structure of the proposed ECM model with the inclusion of up to 3 lags. The test results have been summarised as Table 3. In using an information criterion, the selection rule is that the lag length that minimizes the criterion is the optimal. Hence, according to the test results, the inclusion of the $1^{\text {st }}$ lag is supported by all except SC criterion. But, SC statistic is minimized at zero-lag suggesting static specification. Hence, we decided to begin from the inclusion of the first lag of all the variables as a general unrestricted version of the proposed ECM model.

Table 3. Test results on the lag structure of the ARDL Specification (all in first-differences, sample period: 1950-2003)

\begin{tabular}{llcccc|cccc}
\hline \hline & No. & \multicolumn{4}{c|}{ With no log-likelihood constant } & \multicolumn{4}{|c}{ When log-likelihood constant } \\
\cline { 3 - 9 } Lags & Obs & AIC & SC & HQ & FPE & AIC & SC & HQ & FPE \\
\hline 3 & 50 & -3.135 & -2.217 & -2.785 & 0.047 & -0.297 & 0.621 & 0.053 & 0.810 \\
2 & 51 & -3.169 & -2.487 & -2.908 & 0.043 & -0.331 & 0.351 & -0.070 & 0.741 \\
$\mathbf{1}$ & $\mathbf{5 2}$ & $-\mathbf{3 . 2 7 7}$ & -2.826 & $-\mathbf{3 . 1 0 4}$ & $\mathbf{0 . 0 3 8}$ & $-\mathbf{0 . 4 3 9}$ & 0.011 & $-\mathbf{0 . 2 6 6}$ & $\mathbf{0 . 6 5 0}$ \\
0 & 53 & -3.112 & $-\mathbf{2 . 8 8 9}$ & -3.026 & 0.045 & -0.274 & $-\mathbf{0 . 0 5 1}$ & -0.188 & 0.761 \\
\hline \hline
\end{tabular}

Dependent Variable: Investment; Regressors considered: Lagged Investment, Consumption Return, Government Expenditure, foreign reserve and Trade Openness.

Hence, the unrestricted version of the ultimate ECM model proposed for estimation becomes 


$$
\begin{array}{r}
\Delta y_{t}=v+\lambda \hat{\xi}_{t-1}+\alpha_{1} \Delta y_{t-1}+\sum_{i=1}^{k} \gamma_{i 0} \Delta x_{i, t}+\sum_{i=1}^{k} \gamma_{i 1} \Delta x_{i, t-1}+\varepsilon_{t} \\
\text { Where } \lambda \text { is the coefficient (speed) of }
\end{array}
$$

adjustment,

$$
\begin{aligned}
& \alpha_{1}, \gamma_{i 0} \text { and } \gamma_{i 1} \text { are the short-ran } \\
& \text { coefficients, }
\end{aligned}
$$

$\varepsilon$ is a random disturbance term assumed to be iid, and

$$
\begin{aligned}
& \beta_{i} \text { is the long-run parameter } \\
& \text { computed as }
\end{aligned}
$$

\subsubsection{Statistical Summary of the Data}

$$
\beta_{i}=\frac{\gamma_{i 0}+\gamma_{i 1}}{1-\alpha_{1}}
$$

The statistical summary of the data has been organized in the form of Table 4 so that we can compare the mean of the first-differences (growths) of the variables from the full and the shorter sub-sample periods. The summary statistics indicate that: (i) the average growths of private investment, real per capita GDP and trade openness have shown deceleration, while that of private consumption and political instability dummy have increased. The implication of the latter is that the post-1970 period was politically more turbulent than the pre-1970. (ii) Indicated by the standard deviations, FDI is the most volatile variable followed by foreign reserve, import, export and investment, in that order (see Appendix Table 2 for the correlation matrix of the variables). 
Ethiopian Journal of Economics, Volume XIX, No. 1, April 2010

Table 4. The Statistical Summary of the Variables in their first-differences

\begin{tabular}{|c|c|c|c|c|c|c|c|c|}
\hline \multirow[b]{2}{*}{ Variables } & \multirow[b]{2}{*}{ Description } & \multicolumn{3}{|c|}{ SP I (1950 -2003) } & \multicolumn{4}{|c|}{ SP III (1970 - 2003) } \\
\hline & & Obs & Mean & Obs & Mean & St.Dv. & Min & Max \\
\hline \multicolumn{9}{|c|}{ The first difference of the logs of } \\
\hline$\Delta \mathrm{inv}$ & Gross investment & 53 & 0.086 & 33 & 0.059 & 0.192 & -0.41 & 0.54 \\
\hline$\Delta \mathrm{fdi}$ & Foreign Direct Investment, FDI & - & - & 33 & 0.145 & 3.781 & -8.13 & 10.09 \\
\hline$\Delta \mathrm{rgdppc}$ & Real GDP Per capita (Adj. TOT) & 53 & 0.013 & 33 & 0.008 & 0.079 & -0.23 & 0.22 \\
\hline grgdppc & Growth of Real GDPPC (CS) & 53 & 0.016 & 33 & 0.014 & 0.085 & -0.21 & 0.27 \\
\hline$\Delta$ cons & Private consumption & 53 & 0.046 & 33 & 0.049 & 0.097 & -0.23 & 0.29 \\
\hline$\Delta$ gove & Government expenditure & 53 & 0.078 & 33 & 0.078 & 0.146 & -0.25 & 0.38 \\
\hline$\Delta$ return & Return to capital & 53 & -0.013 & 33 & -0.008 & 0.079 & -0.22 & 0.23 \\
\hline$\Delta$ open & Trade openness & 53 & 0.035 & 33 & 0.027 & 0.149 & -0.29 & 0.51 \\
\hline$\Delta$ export & Real Export value & - & - & 33 & 0.016 & 0.286 & -0.76 & 0.76 \\
\hline$\Delta$ import & Real Import Value & - & - & 33 & 0.050 & 0.300 & -1.13 & 0.88 \\
\hline$\Delta \mathrm{cpi}$ & Consumer price Index & - & - & 33 & 0.065 & 0.087 & -0.10 & 0.31 \\
\hline$\Delta$ fxres & Foreign exchange reserve & 53 & 0.085 & 33 & 0.085 & 0.631 & -1.06 & 1.41 \\
\hline$\Delta$ tele100 & Telephone per 100 inhabitants & - & - & 33 & 0.058 & 0.074 & -0.08 & 0.25 \\
\hline$\Delta^{2}$ tele100 & $2^{\text {nd }}$ difference of tele 100 & - & - & 32 & 0.005 & 0.050 & -0.11 & 0.12 \\
\hline DLIB & Liberalization dummy & 54 & 0.226 & 34 & 0.353 & 0.485 & 0 & 1 \\
\hline DW & War dummy & 54 & 0.660 & 34 & 0.794 & 0.410 & 0 & 1 \\
\hline
\end{tabular}

\subsection{Single Equation ECM Estimation Results and Discussion}

In estimating the above specification, the General-to-Specific (Gets) model selection procedures developed by Krolzig and Hendry (2001) have been employed using the data from the full sample (1950-2003) and two sub-sample periods, 1965-2003 \& 1970-2003. The classification of the sample periods is dictated by the availability of the required data for some of the variables of interest. Following the steps outlined in Krolzig and Hendry (2001, P. 837), our model selection process starts from the General Unrestricted Model (GUM) and proceeds by eliminating statisticallyinsignificant variables with the help of diagnostic checks until the specification is simplified into the final/terminal model where all the variables are significant.

With the application of these procedures, one final model for each has been selected for the full (1950-2003) and the second (1965-2003) sample periods while two independent GUMs are estimated with all significant variables in the second sub-period (1970-2003). According to Krolzig and Hendry (2001), if all variables are significant, the GUM is the final model, and the algorithm stops (P. 837). Hence, the 
discussion rests on the results from the selected/terminal models while the others are also reported for comparison. However, the corresponding estimates in different specifications, in most instances, are observed to be the same in sign and closer in magnitude. Except the marginal detection of autocorrelation (P-value $=0.077$ ) in the $9^{\text {th }}$ specification, the desirable properties of the reported estimations such as normality, no autocorrelation, homoscedasticity and correct functional form specification have been supported by the corresponding diagnostic tests. The test results have been reported in the lower panels of the result tables. The estimates are interpreted as average elasticity parameters indicating the average responsiveness of the growth of private investment to a $1 \%$ change on the growth of a variable.

The results of the estimations and diagnostic tests have been organized in the form of Table 5 in such a way that the upper panels display the estimated parameters and the corresponding P-values in asterisk $\left({ }^{*}\right)$ while diagnostic test results are displayed in the lower panels. Under this section, results from the estimation of four distinct specifications have been discussed. The discussion focuses on the short-run coefficients while the long-run solutions have also been reported in Appendix Tables 3 (A) \& (B).

\section{So, what the evidences tell us about the main determinants of private investment in Ethiopia?}

According to the dominant features of the estimated short-run elasticity coefficients, private investment in Ethiopia is evidenced to be favored by domestic demand, the return to capital, trade openness and liberalization measures, infrastructure, FDI and lagged foreign reserve. The results also cast evidences on the negative determinants to include unfavorable macroeconomic environment, government activities and political instability. The magnitudes of the respective influences and their statistical significance have been detailed as follows.

Domestic demand is one of the strong positive determinants of private investment in Ethiopia. In all of the eight specifications it enters, either represented by private consumption or real per capita GDP growth, it attains all positive coefficients. However, the magnitude and significance of the estimates are found to vary with the 
coverage of the sample periods in that its influence is found to be higher in the recent periods. According to the selected models, on average, a 1 percent positive change in the growth of domestic demand stimulates private investment to grow faster by 0.54 percent, ceteris paribus, with only marginal significance when the sample period covers 1950-2003. But, when the estimation is undertaken on the two sub-sample periods, 1965-2003 and 1970-2003, all the estimates turn significant at 5 percent significance levels in that all of the estimated elasticity coefficients (four) fall in a range of 1.1 to 1.3 percent signifying the elastic response of private investment to a change in domestic market. This range encompasses the estimates of the two selected terminal models rather as lower and upper boundaries. These boundary estimates are obtained with the alternative representation of demand by private consumption in the 1965-2003 and by the growth of per capita GDP in the 19702003 sample-periods. Despite the small gap between the two estimates obtained from the two different sample periods, the higher magnitude of the coefficient of consumption growth is consistent with the emphasis of accelerator investment theory (Samuelson, 1939, P. 75, Sloman, 2003, P. 474, 484-485, Westerhoff, 2006, P. 89) and to the results and discussions in Bhaduri \& Marglin (1990, P. 376), Haas \& Schipper (1998, P. 423-425) and Lim \& McAleer (2002, P. 203).

The next order positive determinant of private investment supported by the estimated evidences is the return to capital represented by the growth of the inverse of real per capita GDP. In spite of its application in published works (Asiedu, 2001, for instance) and the absence of a better alternative measurement for return in developing countries, our use of this proxy is with skeptics and hence, follows cautionary steps; i.e., inspecting the behaviors of its coefficients and the sensitivity of others when estimated with the inclusion and exclusion of demand (particularly consumption) and other variables over the three sample periods. From such attempts, we observe a pattern that the magnitude and statistical significance of the estimated coefficients for the return proxy are independent of variations in specifications, rather, dependent on the time span the sample covers. When it is estimated for the full sample period (1950-2003), its coefficients turn insignificant whether consumption is included or excluded. But, when it is estimated for the later two sub-sample periods, the magnitude of all the estimated four coefficients fall in a range of 0.95 to 1.2 regardless of the exclusion of consumption. Moreover, the strength of the estimates improves as the sample period shortens to the recent, i.e., 
the estimates become insignificant for the sample period (1950-2003); only marginally significant ( 2 out of 3 ) when the sample period is shorted by excluding the earlier 15 years (1965-2003), and strongly significant when the sample period is further shorted into 1970-2003. In addition, the magnitude of the coefficients in the terminal models of the two sub-sample periods, the first with simultaneous inclusion of consumption and the latter with its exclusion, are estimated to be almost equal at about 1.2 implying the elastic response of private investment to changes in the return to capital. According to the estimate, a 1 percent increase in the growth of return to capital could result in an average increase in the growth of private investment in Ethiopia by about 1.2 percent.

Evident from the employment of three optional measures, the third order positive determinant is trade openness and liberalization policies: Vamvakidis' openness measure (trade to GDP ratio), real exports and imports separately, and trade liberalization dummy. The openness variable has entered with strongly significant positive coefficients in all of the six specifications estimated on the full sample period. The estimates turn strongly significant and their magnitudes fall in a range of 0.7 to 0.87 for its current and 0.42 to 0.61 for its one-period lag representations. In reference to the estimates in the final model ( $6^{\text {th }}$ specification), a 1 percent change in the growth of trade openness provides a momentum for private investment in Ethiopia to grow faster by about 0.85 percent in the current year and 0.5 percent in the subsequent year. Similar to the conclusion drawn in Mekonnen (2011b, forthcoming), these results witness the positive and persistent effect of trade openness on private investment in Ethiopia, too. This conclusion is also supported with the alternative inclusion of real values of exports and imports (specification 11) with an intention to realize from which part does the dominant positive effect of openness emanate? The estimated elasticity coefficients of real exports (0.21) and import (0.5) are statistically significant at $5 \%$ and $1 \%$ significance levels, respectively. From the results we deduce that the response of private investment to the same order of changes in real imports is greater than that to real exports. The attempt has also been extended with an alternative inclusion of a dummy variable of liberalization (DLIB) holding dichotomous values: zero for the pre-1991 and 1 for the post-1991 periods signifying its suppression in the former and boost in the latter. The liberalization dummy has strongly significant coefficients both in its current and lag representations as indicated in the $10^{\text {th }}$ specification where all the other openness 
measures are excluded. The striking behavior of the liberalization dummy is its strongly negative coefficient in the current and its strongly significant positive coefficient of its lag. This is similar to Greenaway's et al (1998) findings of the "Jcurve" effect of liberalization on growth interpreted as the first impact of liberalization is negative and its positive effect starts a year after, i.e., its positive effect lags (P. 1556) and our SUR results (Mekonnen, 2011b, forthcoming). Consistently, our ECM estimates reconfirm that the immediate impact of trade liberalization is retarding by half (coeff. $\approx-0.49$ ) while it accelerates the growth of private investment in the subsequent year by the same order of magnitude (coeff. $\approx$ 0.48). However, our attempt to see the sensitivity of the coefficient by taking only its lagged representation in the $11^{\text {th }}$ specification comes out with a negative coefficient with a magnitude of $1 / 4^{\text {th }}$ of its magnitude in the $10^{\text {th }}$ specification. But, it should not be interpreted as a contradicting result; rather, it is indicating the fact that it is picking the outweighing immediate negative impact left uncontrolled when the current representation is removed from the regression. Hence, for reliable estimations, their simultaneous inclusion is recommended. The impact of trade on investment is found also positive and strong; but, a liberalization measure could have a negative repercussion in the first instance while its positive effect lags. In addition, the implementation of these optional proxies has given us an opportunity to observe the immediate positive effect of the trade-outcome measures while an immediate negative followed by a lagging positive effect is found from the use of a liberalization dummy variable.

In spite of similar patterns, there is an interesting one-year difference between the speeds to switch from its significantly negative to its significantly positive effect evidenced in Greenaway's et al (1998) where results behave significantly negative for the current, insignificant for the $1^{\text {st }}$ and significantly positive for the $2^{\text {nd }}$ lags, and our ECM results. But, the differences seem to stem on the employed regressand in that per capita GDP growth is their dependent variable while ours, here, is the growth of private investment. Thus, if trade contributes to income growth through its effect on investment as evidenced in Wacziarg (2001, P. 422), a one-year further lagged positive effect of trade liberalization on income growth or a one-year faster lagged positive effect of liberalization on investment growth seems a plausible patter of outcomes. This was also the pattern of results observed in our recent SUR estimation (see Mekonnen, 2011b, forthcoming). 
The fifth positive determinant, weakly evidenced, is infrastructure proxied by the number of telephone lines and mobiles per 100 inhabitants. However, we remember that this proxy variable is $1(2)$. Therefore, the estimation of this variable and the interpretation of its coefficients need some cautionary steps. So, the cautions we take are: firstly, to exclude it from the estimations of the full sample; secondly, to take its first-difference into the regressions albeit non-stationary following Wilkins' et al (2003) remedial recommendation that suggests the estimation of a nonstationary series in regressions where all the other variables are stationary (P. 78). However, the estimations following this approach do not produce a significant estimate for $\Delta$ tele/100. Hence, we pass into the third step, considering its seconddifference. The estimation of the last specification with the inclusion of $\Delta^{2}$ tele/100 yields a coefficient of 0.99 statistically significant at 95 percent confidence level. According to this coefficient, the response of the growth of private investment in Ethiopia is proportionate to accelerated growth of infrastructural facilities. However, we do not believe that infrastructure is well represented by the number of telephone lines. In spite of its application in many similar empirical researches for its easy data availability, studies argue that telephone lines fail to take into account the potential and the reliability of infrastructure (Asiedu, 2001, P. 111, Astatike and Assefa, 2005, P. 15).

The estimates also provided supports to the complementary role of FDI and the lagging positive effect of foreign reserve albeit weakly. According to the estimates, a 1 percent rise in the growth of FDI perpetuates domestic private investment in Ethiopia to grow faster by about 0.03 percent in the current and 0.02 percent in the next year that could be interpreted as its multifarious contribution to domestic investment; i.e, knowledge/technology transfer, competition, additional demand, etc. But, the coefficients are the smallest of all the estimated positive effects.

Hence, from the positive side of investment determination, we claim to provide strong evidence for the considerable influences of domestic market, return to capital, and trade openness and liberalization measures in that order of magnitude while infrastructure, FDI (small magnitude) and lagged foreign reserve are weakly supported to have positive impacts in the process of promoting private investment in Ethiopia (see Tables 5, A \& B for short-run coefficients). 
The estimations also provide strong evidence for the adverse consequences of macroeconomic instability, government activities and political instability. The variables investigated and supposed to reflect the effects of macroeconomic instability are inflation and foreign reserve. The first variable estimated with consistently negative and robustly significant coefficient is inflation measured by the rate of growth of consumer price index. Besides its robustness, the magnitude of its negative estimates concentrates in a range from 0.7 to 1.2 in all of the specifications it enters. Whether represented by its current or lag values, inflation is estimated to have a strong negative influence on the growth of private investment. According to the $7^{\text {th }}$ specification where it enters in its distributed lag representations, a 1 percent increase in the rate of inflation inflicts the growth of private investment to retard by about 1 percent in the current year and persists to retard it by about 0.9 percent in the subsequent year. When the lag representation is excluded, the magnitude of its negative coefficients increases into about -1.2 as estimated for the first sub-sample ( $8^{\text {th }} \& 9^{\text {th }}$ specifications). But, it is estimated to be -0.74 for the second sub-sample (1970-2003). Nonetheless, it remains the strongest adverse influence in constraining the growth of private investment in the country.

The second variable with consistently negative coefficient on its current representation is the growth of foreign exchange reserve. In all of the ten specifications it enters, the current representation of foreign reserve holds all negative coefficients while eight of them are significant at conventional levels. The coefficients of all the significant estimates lie in a range between -0.08 to -0.1 , regardless of the sample periods. The magnitudes of the insignificant coefficients (in the $3^{\text {rd }} \& 4^{\text {th }}$ specifications) are either close to or fall in the range, i.e., $-0.07 \&-0.08$. Hence, the estimates could be taken as reasonably stable against changes in sample periods and specifications. The estimations from the three selected models are recorded to be -0.105 in the $6^{\text {th }},-0.086$ in the $9^{\text {th }}$ and -0.102 in the $10^{\text {th }}$ specifications. Its interpretation in determining the growth of domestic investment may apparently seem a puzzle in that it looks to vary inversely with the growth of domestic investment. However, it might not be the fundamental positive link between foreign exchange reserve and investment that is broken. Rather, a glance at our graphical diagnosis and descriptive statistics shows us that foreign reserve is one of the variables with unpredictable variations and highest standard deviation 
Ambachew Mekonnen: Determinants of private investment in Ethiopia:...

next to FDI. Mekonnen (2008) describes that foreign exchange reserve in Ethiopia is one of the most erratic macroeconomic variables (P. 45).

Table 5. Single Equation ECM Estimations, (Dependent Variable: Growth of Investment)

(Coefficients of Short-Run Relations and Speed of Adjustment)

(A) Sample Period I

\begin{tabular}{|c|c|c|c|c|c|c|c|}
\hline \multirow{2}{*}{\multicolumn{2}{|c|}{ Regressors }} & \multicolumn{6}{|c|}{ Sample Period I (1950-2003) } \\
\hline & & 1 & 2 & 3 & 4 & 5 & 6 \\
\hline \multirow{13}{*}{ 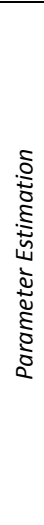 } & Constant & $0.124 * *$ & $0.123^{* * *}$ & $0.151 * * *$ & $0.150 * * *$ & $0.124^{* * *}$ & $0.133 * * *$ \\
\hline & $\Delta$ cons & 0.673 & 0.625 & - & - & $0.554 *$ & $0.540 *$ \\
\hline & $\Delta$ cons_1 & -0.267 & - & - & - & 0.094 & - \\
\hline & $\Delta$ retrun & 0.146 & 0.195 & -0.496 & -0.350 & - & - \\
\hline & sreturn_1 & -0.624 & - & -0.698 & - & - & - \\
\hline & $\Delta$ open & $0.699 * * *$ & $0.875^{* * *}$ & $0.653^{* *}$ & $0.874 * * *$ & $0.760 * * *$ & $0.850 * * *$ \\
\hline & Dopen_1 & 0.424 & $0.454 * *$ & $0.615^{* * *}$ & $0.553^{* * *}$ & $0.484^{*}$ & $0.492 * *$ \\
\hline & $\Delta$ fxres & $-0.095^{*}$ & $-0.090 *$ & -0.082 & -0.072 & $-0.108^{* *}$ & $-0.105 * *$ \\
\hline & $\Delta$ fxres_1 & 0.050 & - & 0.031 & - & 0.035 & - \\
\hline & $\Delta$ gove & $-0.633^{* *}$ & $-0.645^{* * *}$ & $-0.762 * * *$ & $-0.706 * * *$ & $-0.733^{* * *}$ & $-0.718^{* * *}$ \\
\hline & $\Delta$ gove_1 & -0.419 & $-0.424 *$ & $-0.586 * *$ & $-0.521 * *$ & $-0.407^{*}$ & $-0.460 * *$ \\
\hline & $\Delta$ inv_1 & -0.208 & $-0.240 * *$ & $-0.218^{*}$ & $-0.232^{*}$ & $-0.222^{*}$ & $-0.235^{* *}$ \\
\hline & ECM & $-0.305^{* * *}$ & $-0.290 * * *$ & $-0.230 * * *$ & $-0.215^{* *}$ & $-0.264^{* *}$ & $-0.271 * * *$ \\
\hline \multirow{8}{*}{ 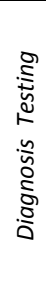 } & $R^{2}$ & 0.55 & 0.54 & 0.53 & 0.50 & 0.54 & 53 \\
\hline & $D W$ & 1.96 & 1.97 & 2.08 & 2.07 & 1.99 & 1.97 \\
\hline & Obs. & 52 & 52 & 52 & 52 & 52 & 52 \\
\hline & $A R 1-2$ & 0.715 & 0.514 & 1.003 & 0.771 & 0.634 & 0.504 \\
\hline & $A R C H 1-1$ & 0.498 & 0.433 & 0.191 & 0.318 & 0.491 & 0.459 \\
\hline & Normality & 3.938 & 3.964 & 2.747 & 1.806 & 4.166 & 4.046 \\
\hline & Hetero & 0.778 & 0.798 & 0.365 & 0.471 & 0.451 & 0.537 \\
\hline & RESET & 0.665 & 0.594 & 0.988 & 0.525 & 0.561 & 0.366 \\
\hline
\end{tabular}


Table 5. Single Equation ECM Estimations, (Dependent Variable: Growth of Investment) (Coefficients of Short-Run Relations and Speed of Adjustment)

(B) Sample Periods II and III

\begin{tabular}{|c|c|c|c|c|c|c|}
\hline \multicolumn{2}{|c|}{ Regressors } & \multicolumn{3}{|c|}{ Sample Period II (1965-2003) } & \multicolumn{2}{|c|}{ "Sample Period III (1970-2003) } \\
\hline & & 7 & 8 & 9 & 10 & 11 \\
\hline \multirow{23}{*}{ 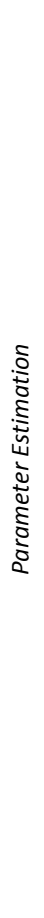 } & Constant & $0.238 * * *$ & $0.187^{* * *}$ & $0.187^{* * *}$ & $0.145^{* * *}$ & $0.089 * * *$ \\
\hline & $\Delta$ cons & $1.318^{* *}$ & $0.325 * *$ & $1.328 * *$ & - & - \\
\hline & $\Delta$ cons_1 & - & - & - & 0.467 & - \\
\hline & grgdppc & - & - & - & $1.109 * *$ & - \\
\hline & $\Delta$ return & 0.952 & $1.236^{*}$ & $1.235^{*}$ & - & $1.184^{* * *}$ \\
\hline & $\Delta$ fxres & $-0.077^{* *}$ & $-0.082^{* *}$ & $-0.086 * *$ & $-0.102 * *$ & - \\
\hline & $\Delta$ fxres_1 & - & - & - & $0.094 *$ & - \\
\hline & $\Delta \mathrm{cpi}$ & - & - & $-1.196 * * *$ & $-0.742 * *$ & - \\
\hline & & $0.961 * * *$ & $1.192^{* * *}$ & & & \\
\hline & $\Delta$ cpi_1 & $-0.853^{* *}$ & - & - & - & - \\
\hline & $\Delta^{2}$ tel $/ 100$ & 0.227 & -0.025 & - & - & $0.988 * *$ \\
\hline & $\Delta^{2}$ tel/100_1 & -0.730 & - & - & - & - \\
\hline & $\Delta$ gove & -0.291 & $-0.348 *$ & $-0.355^{*}$ & $-0.818 * * *$ & - \\
\hline & DW & $-0.105^{*}$ & $-0.119 *$ & $-0.120 * *$ & - & - \\
\hline & DLIB & - & - & - & $-0.491^{* *}$ & - \\
\hline & DLIB_1 & - & - & - & $0.476 * *$ & $-0.123^{* *}$ \\
\hline & $\Delta \mathrm{fdi}$ & - & - & - & - & $0.030 * * *$ \\
\hline & $\Delta$ fdi_1 & - & - & - & - & $0.021 * *$ \\
\hline & $\Delta$ export & - & - & - & - & $0213^{* *}$ \\
\hline & $\Delta$ import & - & - & - & - & $0.505^{* * *}$ \\
\hline & Sinv_1 & 0.085 & $0.255^{*}$ & $0.262 * *$ & 0.137 & -0.172 \\
\hline & ECM & - & - & $-0.395^{* * *}$ & $-0.421 * * *$ & $-0.732 * * *$ \\
\hline & & $0.515^{* * *}$ & $0.389 * * *$ & & & \\
\hline \multirow{8}{*}{ 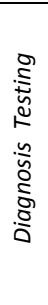 } & $R^{2}$ & 0.76 & 0.67 & 0.68 & 0.69 & 0.78 \\
\hline & $D W$ & 2.03 & 2.39 & 2.43 & 2.12 & 1.99 \\
\hline & Obs. & 38 & 38 & 38 & 32 & 32 \\
\hline & $A R$ 1-2 & 0.418 & 2.602 & $2.818 *(0.077)$ & 0.445 & 0.073 \\
\hline & $A R C H 1-1$ & 1.054 & 0.181 & 0.103 & 0.028 & 0.082 \\
\hline & Normality & 3.138 & 4.040 & 3.775 & 3.147 & 2.260 \\
\hline & Hetero & 0.405 & 1.081 & 0.973 & 0.234 & 0.336 \\
\hline & RESET & 0.400 & 0.421 & 0.441 & 0.185 & 0.091 \\
\hline
\end{tabular}

Note: $1 . \quad{ }^{* *} P<0.01,{ }^{* *} 0.01<P<0.05$ and $* 0.05<P<0.10$;

2. The coefficients for tele/100 in the 7 th and 8 th specifications are for its first difference representation while the $2^{\text {nd }}$-difference is included in the $11^{\text {th }}$.

Thus, its negative coefficients should be taken as indicators of the adverse effect of uncertainty in the macroeconomic environment in general and provision of foreign resources in particular. Moreover, its lag representation attains significantly positive 
coefficient in the $10^{\text {th }}$ specification. Hence, it is rather legitimate to think that the positive effect of foreign reserve lags. However, its instability would have been causing uncertainty and hurting domestic investment. Thus, based on the two proxies, we perceive that imprudent macroeconomic management was one of the obstructions of private investment in Ethiopia.

In order of magnitude, the next constraint identified is the crowding-out effect of government activities as proxied by government expenditure. In all of the 10 specifications it enters, its coefficients are estimated statistically significantly negative for both its current and lag representations. In the first six specifications estimated for the full sample period, the coefficients on its current representation fall in a range between -0.63 to -0.76 ; and, on its lag between -0.41 and -0.6 . It has also been estimated as high as -0.82 for the second sub-sample period excluding its lag. This finding could be interpreted as the crowding-out effect of government expenditure through its impacts of reducing saving, increasing interest rates and prices of intermediate inputs in the market. Otherwise, it might be picking up the negative impact of lack of good governance in the country and war. Whilst the exclusion of its lag could have contributed to the rise in its estimated magnitude, the latter sub-period is also identified as politically more turbulent than the earlier. This fact is indicted by the mean of the war dummy (DW) variable that is greater in the 1970-2003 period. Thus, we expect that the strong negative effect of government expenditure might have been magnified by similar effects of war and violencerelated spending. In support of this presumption, the correlation coefficient of the two variables is referred to be about 0.17 (Appendix Table 2). Therefore, with an anticipated interaction between them, all the three equations of the first sub-period (1965-2003) are estimated with the simultaneous inclusion of the two variables where both are estimated with marginal significances but stable magnitudes; i.e., coef. of $\Delta$ gove $\approx-0.30$ to -0.36 and coef. of $D W \approx-0.10$ to -0.12 . In addition, our further attempt with the exclusion of the war dummy and its lag, and the estimation for the second sub-period clearly reveals its highest negative estimate (above a fold). From the estimates, we draw some conclusions, i.e., the effect of government expenditure is strongly supported to harm the growth of private investment. However, its coefficients should not be interpreted as the only crowding-out effect. The adverse consequences of war and violence seem compounded within it. The reduced magnitudes and their merely marginal significances when they enter 
simultaneously and the existence of considerable interaction between the two variables are in support of this argument. Any how, government expenditure and political instabilities are among the main culprits of private investment in Ethiopia. Thus, from the negative side also, the investigation claims to identify three constraints of private investment; i.e., unfavourable macroeconomic environment, government activities and political instabilities (see Appendix Tables 3, A \& B for the long-run solutions).

In addition to the identification of the main positive determinants (demand, return to capital, trade openness and liberalization measures, FDI and lagged foreign reserve) and negative determinants (macroeconomic and political instability \& the crowding-out consequences of government activities), there are also some other observed coincidences and tendencies, such as:

i. The estimates for trade openness and government activities, without the separate consideration of war and political influences, are nearly equal in magnitude but opposite in sign (the first six specifications) implying that the positive attribute of openness to trade seems fully cancelled-out by government intervention and war related activities.

ii. As expected, the magnitudes of the long-run elasticity coefficients are estimated greater than their short-run counterparts.

i. The speed of adjustment $(\lambda)$ is low $(-0.3 \leq \lambda \leq-0.2)$ when the sample period covers 1950-2003 signifying the relative rigidity of the earlier, but, relatively faster adjustment $(-0.7 \leq \lambda \leq-0.4)$ in the latter two sub-sample periods. It is consistently estimated to be significantly negative. According to Banerjee et al (1986, 1993) ECM test, its significance indicates the existence of cointegration, and adjustment process towards the long-run equilibrium (Banerjee et al, 1986, P. 265, 1998, P. 268). Its negative appearance implies the positive short-run deviation from and then the downward adjustment process towards the equilibrium such that the equations are dynamically stable.

Nonetheless, all the above estimations are based on the implicit assumption of nonsimultaneity among the dependent and the explanatory variables. However, such a decision is subjective and has been criticized by Christopher Sims (1980). According to him, if there is true simultaneity among a set of variables, all should be treated on 
an equal footing; there should not be any a priori distinction between endogenous and exogenous variables (Gujarati, 1995, P. 746, Asteriou and Hall, 2007, P. 279). Hence, we suggest further research on the dynamic interdependence between investment, trade policy and growth, using VAR methodology allowing for simultaneity and avoiding a priori subjective classification of variables into endogenous and exogenous, possibly with the incorporation of the recent data series.

\section{Conclusion}

The Ethiopian private investment performance has been weak for long time. It had been stagnantly low until the end of the socialist regime. Domestic private investment has started to rise since 1992 while FDI did since 1996. FDI was also contracted during the 1998-2000 border war and few years following the 2005 national election. Investment is one of the volatile macroeconomic variables. But, FDI is 20 times more volatile than domestic private investment; i.e. the standard deviation of $\Delta$ fdi is 3.78 while that of $\Delta i n v$ is 0.19 .

In the attempt to identify the main determinants, among the variables considered, investments is evidenced to be affected favourably by the growth of domestic market (growths of private consumption or per capita income), return to investment (as proxied by the inverse of real GDP), government policies promoting openness and liberalization, infrastructure (weakly proxied by the number of telephone subscribers) and FDI; and, negatively by macro-economic instability (inflation and foreign exchange reserve), government expenditure, and political instability (war).

Thus, we recommend that enhancing trade liberalization and openness, augmenting domestic market and the return to investment, maintaining macroeconomic stability (particularly stable price level and provision of foreign exchange) and securing political stability could favour investment in the country. Improving the availability and reliability of infrastructural facilities and investment friendly government interventions should be among the main ingredients of a policy package designed to promote private investment in Ethiopia. The operation of the public sector and other institutions will also need new thinking. 
FDI in Ethiopia is found to be complementary to domestic investment. However, FDI is found to be the most volatile variable followed by foreign exchange reserve. Hence, it leads us to conclude that FDI in Ethiopia needs special care and more anxiety compared to that of domestic investment. On the other hand, the dominant form of investment in Ethiopia is domestic. Thus, we suggest that Ethiopia should give primary attention to promoting domestic investment. The successes on domestic investment could also serve as an attraction to FDI.

\section{References}

Asiedu, E. (2002) "On the Determinants of Foreign Direct Investment to Developing Countries: Is Africa Different?". World Development, Vol. 30, No. 1, P. 107-119, Elsevier Science Ltd.

Astatike, G. and Assefa, H. (2006) "Determinants of Foreign Direct Investment in Ethiopia: A time Series Analysis". Policy Studies Institute, London.

Asteriou, D. and Hall, S. G. (2007) "Applied Econometrics: A Modern Approach Using EViews and Microfit". Revised Edition, Palgrave Macmillan, New York.

Banerjee, A., Dolado, J., Hendry, D. and Smith, G. (1986) "Exploring Equilibrium Relationships in Econometrics through Static Models: Some Monte Carlo Evidence". Oxford Bulletin of Economics and Statistics, Vol. 48, No. 3, P. 253-277.

Banerjee, A., Dolado, J., and Mestre, R. (1986) "Error-Correction Mechanism Tests for Cointegration in a Single-Equation Framework". Journal of Time Series Analysis, Vol. 19 , No. 3, P. 267-283.

Blejer, M. I. and Khan, M. S. (1984) "Government Policy and private Investment in Developing Countries". IMF Staff Papers, Vol. 31, No. 2, P. 379-403.

Dollar, D. and Easterly, W. (1999) "The Search for the Key: Aid, Investment and Policies in Africa". Journal of African Economies, Volume 8, No. 4 P. 546-577.

Fielding, D. (1993) "Determinants of Investment in Kenya and Cote d"Ivoire". Journal of African Economies, Vol. 2, No. 3, P. 299 -328, University of Oxford.

Greenaway, D., Morgan, W. and Wright, P.W (1998) "Trade Reform, adjustment and growth: What Deos the Evidence tell us?". The Economic Journal, Royal Economic Society, Balckwell Publishers, Oxford, P. 1547-1561. 
Greene, J. (1991) "Private Investment in Developing Countries: An Empirical Analysis".

IMF, Vol. 38, No. 1, P. 33.

Greene, W. H. (2003) "Econometric Analysis". $5^{\text {th }}$ Edition, Prentice Hall, New Jersey.

Hansson, I. (1986) "Classical, Keynes and Neoclassical Investment Theory - A synthesis". Oxford Economic Papers 38, P. 305-316, Oxford University Press.

Haas, R. and Schipper, L. (1998) "Residential energy demand in OECD-countries and the role of irreversible efficiency improvements". Energy Economics, Vol. 20, issue 4, P. 421442, Elsevier Science B.V.

Hassler, U. And Wolters, J. (2006) "Autoregressive Distributed Lag Models and Cointegration". Allgemeines Statistisches Archiv, 90, P. 59-74. Physica-Verlag, ISSN 00026018.

Janicki, H. P. and Wunnava, P. V. (2004) “Determinants of foreign direct investment: empirical evidence from EU accession candidates". Applied Economics, Vol. 36, 505-509. Routledge, Taylor and Francis Group.

Jenkins, C. (2010) "Determinants of Private Investment in Zimbabwe". Journal of African Economies, Vol. 7. No. 1, P. 34-61.

Jones, C. (1998) "Introduction to Economic Growth". 21 $1^{\text {st }}$ Edition, W.W. Norton \& Co, London.

Jones, C. (2002) "Introduction to Economic Growth". $2^{\text {nd }}$ Edition, W.W. Norton \& Co, London.

Jorgenson, D. W. and Siebert, C. D. (1968) "A Comparison of Alternative Theories of Corporate Investment Behaviour". The American Economic Review, Vol. 58, No. 4, P. 681-712.

Jorgenson, W. D. (1996) "Investment Volume 1: Capital theory and Investment behavior". The MIT Press, Cambridge.

Kahai, S. K. (2004) "Traditional And Non-Traditional Determinants Of Foreign Direct Investment in Developing Countries". Journal of Applied Business Research, Vol. 20, No. 1.

Krolzig, H. M. and Hendry, D. (2001) "Computer automation of general-to-specific model selection procedures". Journal of Economic Dynamics \& Control, 25, P. 831- 866, Elsevier Science B.V.

Lee, J. (2003) "Government Policies and Foreign Direct Investment in Developing Countries". Texas A\&M University-Corpus Christi.

Lewis, W. A. (1965) "Theory of Economic Growth". George Allen \& Unwin Ltd, London.

Lim, C. and McAleer, M. (2001) "Cointegration analysis of quarterly tourism demand by Hong Kong and Singapore for Australia". Applied Economics, Vol. 33, P. 15991619. Taylor \& Francis Itd. 
Lim, C. and McAleer, M. (2002) "A cointegration analysis of annual tourism demand by Malaysia for Australia". Mathematics and Computer in Simulation, Vol. 59, Issue 13, P. 197-205, Elsevier Science B.V.

Lucas, R. (1990) "Why doesn't Capita Flow from Rich to Poor Countries?". The American economic review, Vol. 80, No. 2, P. 92-96.

Mekonnen, A. (2008) "Performance and Main Determinants of Investment in Ethiopia". MSc Thesis, University of Kent.

Mekonnen, A. (December 2011a) "The Investment, Trade and Growth Nexus in Sub-Saharan Africa". Journal of African Development Studies, Vol. 3, No. 2, P. ___ (forthcoming).

Mekonnen, A. (December 2011b) "The Dynamic Links between Investment, Trade Openness and Growth in SSA". Journal of African Development Studies, Vol. 3, No. 2, P. (forthcoming).

Ndikumana, L. (2005) "Can macroeconomic policy stimulate private investment in South Africa? New insights from aggregate and manufacturing sector-level evidence". Working Paper 2005-14. University of Massachusetts.

Ndikumana, L. and Verick, S. (2008) "The Linkages between FDI and Domestic Investment: Unravelling the Developmental Impact of Foreign Investment in Sub-Saharan Africa". Discussion Paper No. 3296, University of Massachusetts, UNECA and IZA.

Nonnemberg, M.B. and Mendonca, M.J. (2004) "The Determinants of Foreign Direct Investment in Developing Countries". http://www.anpec.org.br/encontro2004/artigos/A04A061.pdf.

Oshikoya, T. W (1994) "Macroeconomic Determinants of Domestic Private Investment in Africa: An Empirical Analysis". Economic Development and Cultural Change. The University of Chicago.

Ouattara, B. (2004) "Modeling the Long Run Determinants of private Investment in Senegal". Credit Research Papers, No. 04/05.

Pesaran, M.H., and Shin, Y. (1999) "An Autoregressive Distributed-Lag Modelling Approach to Cointegration Analysis". In Econometrics and Economic Theory in the 20th

Century, The Ragnar Frisch Centennial Symposium, P. 371- 413, Cambridge University Press, Cambridge.

Ramirez, D. M. (1994) "Public and Private Investment in Mexico, 1950-90: An Empirical Analysis". Southern Economic Journal, Vol. 61, No. 1, P. 1-17.

Reppas, P. A. and Christopoulos, D. K. (2005) "The export-output growth nexus: Evidence from African and Asian countries". Journal of Policy Modeling, Vol. 27, No. 8, P. 929940, Elsevier.

Romer, D, (2006) "Advanced Macroeconomics", Third edition, McGraw-Hill Companies, Inc., New York. 
Sakr, K. (1993) "Determinants of Private Investment in Pakistan". IMF, Working Paper No. $93 / 30$.

Salahuddin, M. and Islam, R. (2008) "Factors Affecting Investment in Developing Countries: a Panel Data Study". Journal of Development Areas, Vol. 42, No. 1, P. 21-37.

Samuelson, P. (1939) "Interactions between the Multiplier Analysis and the Principle of Acceleration". The Review of Economics and statistics, Vol. 21, No. 2 P. 75 78. The MIT Press.

Selvam, J. (2007) "Privatization Programme in Ethiopia: Is the Cause Justified?". African Renaissance, Vol. 4, No. 1, P. 66-75.

Shiimi, I. W. and Kadhikwa, G. (1999) "Saving and Investment in Namibia". Bon Occasional Paper No. 2.

Sloman J. (2003) "Economics". $5^{\text {th }}$ Ed. Pearsons Education Limited, Essex, England.

Song, H., Liu, Z. and Ping, J. (2001) "Analysing the determinants of China's aggregate investment in the reform period". China Economic Review, Vol. 12, P. 227-242, Elsevier Science Inc.

Sorensen, P. B. and Whitta-Jacobsen, H. J. (2005) "Introducing Advanced Macroeconomics: Growth and Business Cycles". McGraw-Hill Education, Berkshire.

Thirlwall, A. P (2003) "Growth and Development: With Special Reference to Developing Economies". Seventh edition, Palgrave Macmillan, New York.

Toit, C. and Moolman, E. (2004) "A neoclassical investment function of the South African economy". Economic Modeling, Vol. 21, P. 647-660, Elsevier B.V.

UNCTAD (2002) "Investment and Innovation Policy Review: Ethiopia". United Nations Publication.

UNCTAD (2006) "FDI from developing and transition economies: implications for development". World Investment Report 2006, Fact Sheet: Ethiopia.

Wacziarg, R. (2001) "Measuring the Dynamic Gains from Trade". The World Bank Economic Review, Vol. 15, No. 3, P. 393-429.

Wai, U.T. and Wong, C. (1982) "Determinants of Private Investment in Developing Countries". Journal of Development Studies, Vol. 19, No. 1, P. 19-36.

Westehoff, F. (2006) "Samuelson's multiplier-accelerator model revisited". Applied Economics Letters, Vol. 13, P. 89-92. Taylor and Francis.

Wilkins, N. Yurekli, A. and Hu, T. (2003) "Economic Analysis of Tobacco Demand". Economics of Tobacco Toolkit, Tool 3, Demand Analysis, The World Bank. 
Appendix Table 1. Variables, Measurement Units and Data Sources

\begin{tabular}{|c|c|c|c|c|}
\hline \multicolumn{2}{|c|}{ Catagory } & Variables & $\begin{array}{l}\text { Measurement } \\
\text { Units }\end{array}$ & Sources \\
\hline \multirow{2}{*}{\multicolumn{2}{|c|}{ Dependent variable }} & Investment & 2000 Constant \$ & Generated from PWT Ver. 6.2, 2006 \\
\hline & & & Price & \\
\hline \multirow{25}{*}{ 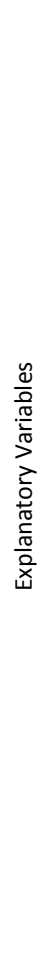 } & Domestic Market & Consumption & 2000 Constant \$ & Generated from \\
\hline & $\&$ & & Price & Summers \& Heston \\
\hline & \multirow[t]{6}{*}{ Return } & Gov't Exp. & 2000 Constant \$ & PWT Ver. 6.2, 2006 \\
\hline & & & Price & \\
\hline & & Real GDPPC & $\$, 2000 \mathrm{Co} / \mathrm{P}$ & PWT Version 6.2, 2006 \\
\hline & & & (Adj. TOT) & \\
\hline & & RGDPPC Growth & \% (2000 Con\$ P, & \\
\hline & & & CS) & \\
\hline & \multirow{7}{*}{$\begin{array}{l}\text { Trade Openness \& } \\
\text { Liberalization }\end{array}$} & Openness & $\mathrm{X}+\mathrm{M} / \mathrm{GDP}(\%)$ & PWT Version 6.2, 2006 \\
\hline & & Exports & Million, Nat. & \\
\hline & & (deflated) & currency & IMF, IFS database, 2005 \\
\hline & & Imports & Million, Nat. & \\
\hline & & (deflated) & Currency & \\
\hline & & LIB. dummy & 0 for pre-1991 \& & MEDaC, Ethiopia, \\
\hline & & & 1 for post-1991 & \\
\hline & \multirow[t]{2}{*}{ FDI } & FDI & Million \$, 2000 & UNCTAD, online data \\
\hline & & & $\mathrm{CP}$ & base, 2007 \\
\hline & \multirow[t]{2}{*}{ Infrastructure } & Tele per 100 & \multirow[t]{2}{*}{ Number } & UNCTAD, Common \\
\hline & & inhabitants & & database, 2008 \\
\hline & Macroeconomic & Forex Reserve & US \$ & \\
\hline & Stability & Inflation & CPI $(2000=100)$ & IMF, IFS Tables, 2005 \\
\hline & \multirow[t]{4}{*}{ Political Instability } & War dummy & 1 for politically & Military, Armed Conflict \\
\hline & & & turbulent \& war & $\underline{\text { Database, Michigan }}$ \\
\hline & & & years and 0 & State University, 2008 \\
\hline & & & otherwise & \\
\hline
\end{tabular}

Note: Investment, consumption and government expenditure figures are in per capita terms. 
Ambachew Mekonnen: Determinants of private investment in Ethiopia:...

Appendix Table 2. Correlation Matrix of the Variables, Computed from the third Sample

(1970 - 2003)

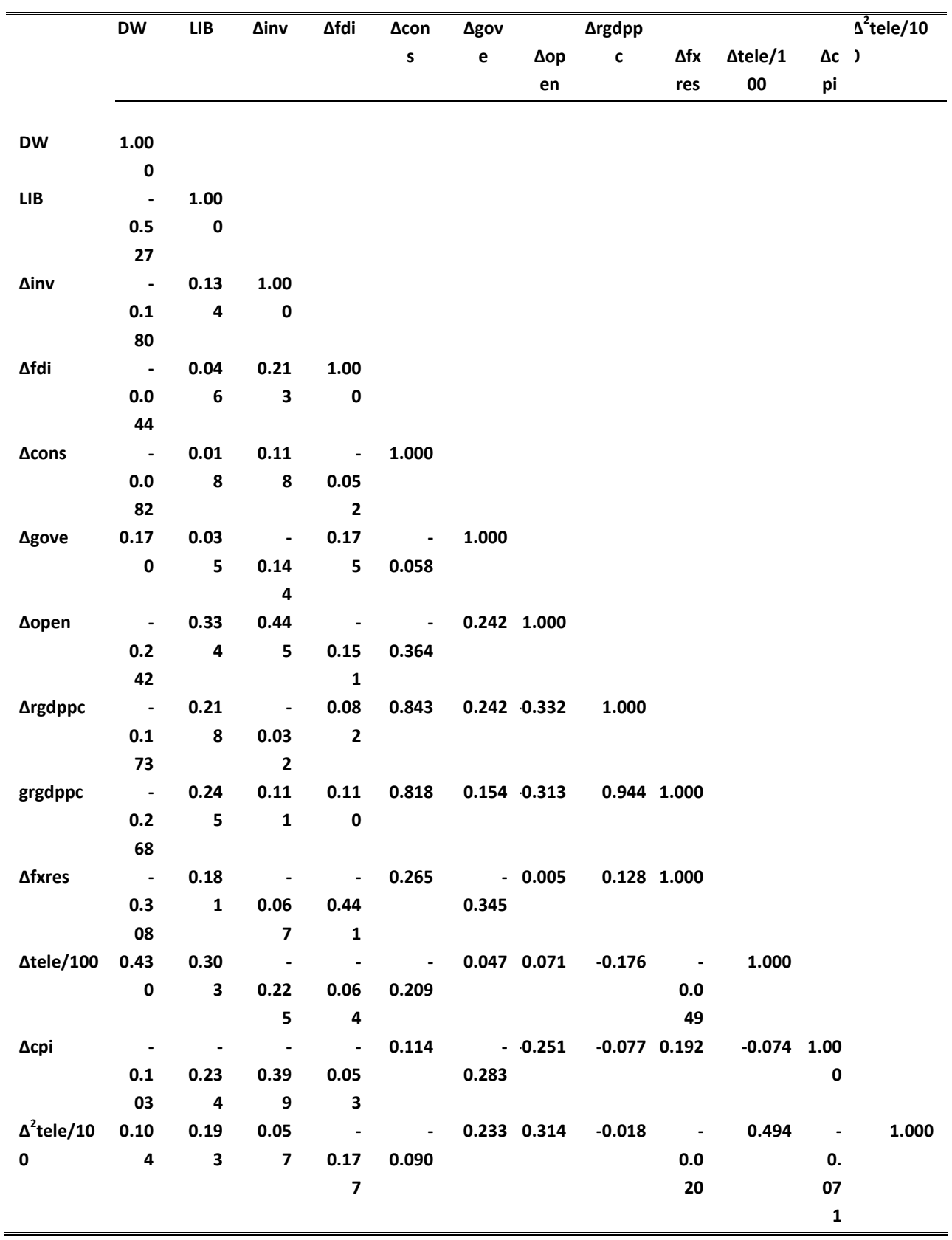


Appendix Table 3. Long-run Solutions from Single Equation ECM Estimations

(A) Sample Period I (1950 - 2003)

(Dependent Variable: Growth of Domestic Private Investment)

\begin{tabular}{|c|c|c|c|c|c|c|c|}
\hline \multicolumn{2}{|c|}{ Regressors } & \multicolumn{6}{|c|}{ Sample Period I (1950-2003) } \\
\hline & & 1 & 2 & 3 & 4 & 5 & 6 \\
\hline \multirow{7}{*}{ 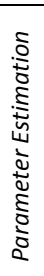 } & Constant & $0.103^{* * *}$ & $0.100 * * *$ & $0.124^{* * *}$ & $0.122^{* * *}$ & $0.101^{* * *}$ & $0.108^{* * *}$ \\
\hline & $\Delta$ cons & 0.336 & 0.504 & - & - & 0.530 & 0.438 \\
\hline & $\Delta$ return & -0.395 & 0.158 & -0.980 & -0.284 & - & - \\
\hline & $\Delta$ open & $0.930 * * *$ & $1.072^{* * *}$ & $1.041 * * *$ & $1.158 * * *$ & $1.018^{* * *}$ & $1.087^{* * *}$ \\
\hline & $\Delta$ fxres & -0.037 & $-0.072^{*}$ & -0.042 & -0.059 & -0.060 & $-0.085^{* *}$ \\
\hline & $\Delta$ gove & $-0.871 * * *$ & $-0.862 * * *$ & $-1.107^{* * *}$ & $-0.996 * * *$ & $-0.933 * * *$ & $0.954 * * *$ \\
\hline & ECM & $-0.252^{* *}$ & $-0.234 * * *$ & $-0.189 * *$ & $-0.174 * *$ & $-0.216^{* *}$ & $-0.220 * * *$ \\
\hline \multicolumn{2}{|c|}{ Wald Test: $\chi 2$} & $35.887^{* * *}$ & $44.350 * * *$ & $34.599 * * *$ & $39.183^{* * *}$ & $36.815^{* * *}$ & $44.418^{* * *}$ \\
\hline
\end{tabular}

Note: $1 . \quad * * * P<0.01, * * 0.01<P<0.05$ and $* 0.05<P<0.10$

2. The Wald test is a joint significance test of the estimated long-run coefficients excluding the constant term.

3. according to Banerjee et al, the significance of the ECM term implies that the underlying variables are cointegrated (1986, P. 265, 1998, P. 268).

(B) Sample Period II (1965 - 2003) and Sample Period III (1970-2003)

(Dependent Variable: Growth of Domestic Private Investment)

\begin{tabular}{|c|c|c|c|c|c|c|}
\hline \multicolumn{2}{|c|}{ Regressors } & \multicolumn{2}{|c|}{ Sample Period II (1965-2003) } & \multicolumn{3}{|c|}{ Sample Period III (1970-2003) } \\
\hline & & 7 & 8 & 9 & 10 & 11 \\
\hline \multirow{14}{*}{ 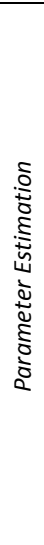 } & Constant & $0.260 * * *$ & $0.250 * * *$ & $0.254^{* * *}$ & $0.168 * * *$ & $0.077^{* * *}$ \\
\hline & $\Delta$ cons & $1.440 * *$ & 1.778* & $1.799 * *$ & 0.541 & - \\
\hline & $\operatorname{grgdppc}(\mathrm{cs})$ & - & - & - & $1.287 * *$ & - \\
\hline & $\Delta$ return & 1.040 & 1.659 & 1.673 & - & $1.020 * * *$ \\
\hline & $\Delta$ fxres & $-0.084 *$ & $-0.110 *$ & $-0.116 * *$ & -0.009 & - \\
\hline & $\Delta c p i$ & $-1.982^{* * *}$ & $-1.600 * * *$ & $-1.621 * * *$ & $-0.860 * *$ & - \\
\hline & $\Delta 2$ tel $/ 100$ & -0.550 & -0.033 & - & - & $0.871^{* *}$ \\
\hline & $\Delta$ gove & -0.318 & -0.466 & -0.481 & $-0.949 * * *$ & - \\
\hline & DW & -0.115 & $-0.160^{*}$ & $-0.163^{*}$ & - & - \\
\hline & DLIB & - & - & - & -0.018 & $-0.108^{* *}$ \\
\hline & $\Delta \mathrm{fdi}$ & - & - & - & - & $0.044^{* * *}$ \\
\hline & $\Delta$ export & - & - & - & - & $0.188^{* *}$ \\
\hline & $\Delta$ import & - & - & - & - & $0.419 * * *$ \\
\hline & ECM & $-0.563^{* * *}$ & $-0.523 * * *$ & $-0.535^{* * *}$ & $-0.488 * * *$ & $-0.625 * * *$ \\
\hline \multicolumn{2}{|c|}{ Wald Test: $\chi 2$} & $34.684^{* * *}$ & $18.235^{* *}$ & $18.817^{* * *}$ & $16.835^{* *}$ & $54.5^{* * *}$ \\
\hline
\end{tabular}

2. The coefficients for tele $/ 100$ in the $7^{\text {th }}$ and $8^{\text {th }}$ specifications are for its first difference representation. 
Ambachew Mekonnen: Determinants of private investment in Ethiopia:...

124 